\title{
Molecular Indices of Neuronal and Glial Plasticity in the Hippocampal Formation in a Rodent Model of Age-Induced Spatial Learning Impairment
}

\author{
Kiminobu Sugaya, ${ }^{1}$ Michael Chouinard, ${ }^{1}$ Rhonda Greene, ${ }^{1}$ Michael Robbins, ${ }^{1}$ David Personett, ${ }^{1}$ \\ Caroline Kent, ${ }^{1}$ Michela Gallagher, ${ }^{2}$ and Michael McKinney' \\ ${ }^{1}$ Department of Pharmacology, Mayo Clinic Jacksonville, Jacksonville, Florida 32224, and ${ }^{2}$ Department of Psychology, \\ University of North Carolina, Chapel Hill, North Carolina 27599
}

Spatial learning ability was quantitated in young and aged Long-Evans rats, and molecular markers were assessed in the striatum and hippocampal formation using immunocytochemical, immunoblotting, and in situ hybridization histochemical procedures. The mRNA for $\beta$-amyloid precursor protein ( $\beta$ APP), most likely the transcript encoding the 695-amino acid form of this protein, was elevated in pyramidal and granule cells in the hippocampus of aged rats exhibiting poorer spatial learning. In immunoblots of hippocampal protein extracts, however, the level of $\beta$ APP-like immunoreactivity was depressed in the more impaired subjects. Similarly, the level in hippocampus of the mRNA for manganese-dependent superoxide dismutase (MnSOD), a marker of oxidative stress, was positively correlated with the degree of behavioral impairment, but immunoblotting revealed that $M n-S O D$ protein was depressed in the aged hippocampus compared with young. The mRNAs for the neuronal form of nitric oxide synthase and for the astrocyte marker glial fibrillary acidic protein (GFAP) were elevated in the hippocampus in correlation with the extent of learning impairment. In the striatum, the levels of mRNA and protein for several candidate genes, including GFAP, were elevated in parallel with the learning index, but these were age effects. Several hippocampal proteins were unchanged (GFAP) or depressed ( $\beta A P P$ and Mn-SOD) in level, despite elevations in corresponding mRNAs. In the aged cohort, hippocampal GFAP mRNA, Mn-SOD mRNA, and $\beta$ APP emerged as predictors of behavioral impairment, suggesting the involvement of these hippocampal systems in age-related cognitive impairment.

Key words: cognition; spatial learning; messenger RNA; immunoblotting; in situ hybridization histochemistry; aging
Cognitive decline in aging, exemplified by impairment of spatial learning in rats, is generally thought to involve substrates in the hippocampus. Causative factors for hippocampal dysfunction are likely to include oxidative stress. Cellular biochemical systems dealing with oxidative stress are altered in both Alzheimer's disease (AD) brain (Martins et al., 1986; Adams et al., 1991; Beal, 1992; Pappolla et al., 1992) and the "normal" aging brain (Halliwell et al., 1989; Reiter, 1995). The SOD enzymes serve as major cellular antioxidant systems (Halliwell and Gutteridge, 1989). Superoxide dismutase activity is elevated by brain ischemia (Sutherland et al., 1991); SOD in vitro protects neurons from hypoxia (Kinoshita et al., 1991); and mice transgenic for $\mathrm{Cu} / \mathrm{Zn}$-dependent superoxide dismutase $(\mathrm{Cu} / \mathrm{Zn}-\mathrm{SOD})$ are protected from ischemia (Kinouchi et al., 1991). The SODs also protect cells from degeneration caused by cytokines (Masuda et al., 1988; Wong et al., 1988, 1989; Baglioni, 1992; Hiraishi et al., 1992; Pang et al., 1992), which in the brain are released from activated glia (Giulian et al., 1994). Glial activation is an established feature of the aging brain, especially the hippocampal formation (Landfield et al., 1977; Geinisman and Dodge, 1978; Lindsey et al., 1979; Adams et al., 1982). Thus, cognitive decline in aging could involve neuronal oxidative stress resulting from loss of control of free radicals,

\footnotetext{
Received Nov. 30, 1995; revised Feb. 20, 1996; accepted March 4, 1996.

This research was supported by the Mayo Foundation, the Adler Foundation, and National Institute on Aging Grants PO1 AG09973 and RO1 AG12653.

Correspondence should be addressed to Dr. Michael McKinney, Department of Pharmacology, Mayo Clinic Jacksonville, 4500 San Pablo Road, Jacksonville, FL 32224.

Copyright $(\mathcal{C} 1996$ Society for Neuroscience $0270-6474 / 96 / 163427-17 \$ 05.00 / 0$
}

perhaps caused by cytokines released from chronically activated glia. As well, glial or neuronal nitric oxide synthase (NOS) could contribute to neuronal oxidative stress (Dawson, 1994), because nitric oxide (NO) can react with superoxide to form peroxynitrite, a neurotoxin. Thus, in addition to protecting neurons from superoxide, SOD could protect against NO challenge (Lafon-Cazal et al., 1993).

The $\beta$-amyloid precursor protein ( $\beta$ APP) family serves roles in neuronal plasticity and survival in the normal brain, whereas aberrant processing of these proteins leads to plaque deposition in AD (Selkoe, 1994). Disruption of energy metabolism has pronounced effects on $\beta A P P$ metabolism (Gabuzda et al., 1994). $\beta A P P$ fragments elicit free radical-mediated protein and lipid peroxidation, and cytotoxicity in neuronal preparations (Behl et al., 1994; Butterfield et al., 1994; Harris et al., 1995). The secreted forms of $\beta \Lambda \mathrm{PP}$ appear to be neuroprotective (Mattson et al., 1993; Smith-Swintosky et al., 1994) and can protect cells from the oxidative injury produced by the $A \beta$ peptide (Goodman et al., 1994). AD senile plaques are surrounded by astrocytes expressing high levels of Mn-dependent superoxide dismutase (Mn-SOD), suggesting that oxidative stress may be associated with amyloid deposition (Furuta et al., 1995).

We have designed analyses of mRNA and protein for a set of genes likely to be informative for the existence of neuronal/glial plasticity responses to oxidative stress; these include Mn-SOD, $\mathrm{Cu} / \mathrm{Zn}-\mathrm{SOD}$, glial fibrillary acidic protein (GFAP), b-NOS, and $\beta A P P$. These indices were assessed in a rodent model that exhibits "naturally" a variable degree of cognitive dysfunction, which was quantitated as spatial learning ability in individual subjects. Our 
results support the view that the hippocampus is affected in specific, complex, and unique ways by the aging process.

\section{MATERIALS AND METHODS}

Experimental subjects. Young and aged male rats were 6 months and $27-28$ months, respectively, at the time of the experiments. The aged rats werc obtaincd as specific pathogen-frce (SPF) retired breeders at 8-9 months of age from Charles River Laboratories (Raleigh, NC). The young subjects were obtained as SPF rats from the same source and were residents in the Psychology Department (University of North Carolina, Chapel Hill) vivarium for at least 2 months before they were killed. The vivarium is on a $12 \mathrm{hr}$ light/dark cycle (lights on at 7:00 A.M.) and climate controlled at $25^{\circ} \mathrm{C}$. The health of all subjects was assessed by routine examination during the experiment and by necropsies performed at the time of killing. All rats included in the neurobiological studies were determined to be healthy. Screcning for a panel of viral antibodies was done on blood samples obtained at the time of killing for a randomly selected subset of the aged rats. These were negative, confirming the SPF status of the animals.

Water-maze testing. The rats were trained on a spatial learning task in the Morris water maze, which required them to use distal cues in the maze environment to learn the position of a camouflaged escape platform. The water maze consisted of a large, circular tank (diameter 183 $\mathrm{cm}$; wall height $58 \mathrm{~cm}$ ). It was filled with water $\left(27^{\circ} \mathrm{C}\right)$ opacified by the addition of powdered milk $(0.9 \mathrm{~kg})$. A retractable white escape platform (height $34.5 \mathrm{~cm}$ ) was located $1 \mathrm{~cm}$ beneath the water surface near the center of one of the four quadrants in the maze. White curtains completely surrounded the maze, and large geometric designs were attached to the curtains to provide spatial cues. Data were analyzed using an HVS Image Analyzing VP-116 video tracking system and an IBM PC with software developed by HVS Imaging (Hampton, UK).

The place training protocol has been described previously in detail (Gallagher et al., 1993). Briefly, the rats received three trials per day for eight consecutive days using a $60 \mathrm{sec}$ intertrial interval. A training trial consisted of placing the animal in the water for $90 \mathrm{sec}$ or until the rat found the platform. If the rat failed to find the platform within the $90 \mathrm{sec}$, the animal was placed by the experimenter on the platform for $30 \mathrm{sec}$. For spatial learning assessment, the platform's location remained constant in one quadrant of the maze, but the starting position for each trial was varied among four equally spaced positions around the perimeter of the maze to preclude the development of a response strategy. Every sixth trial was a probe trial, during which the platform was retracted to the bottom of the pool for $30 \mathrm{sec}$ and then raised and made available for escape. The training trials assessed the acquisition and day-to-day retention of the spatial task, and the probe tests were used to assess the scarch stratcgy the rat used to navigate in the maze. At the completion of spatial learning assessment, one session with six trials of cue training was performed. Rats were trained to escape to a visible black platform, rising $2 \mathrm{~cm}$ above the surface of the water. The location of the platform was varied from trial to trial to assess sensorimotor and motivational functioning independent of spatial learning ability. Each rat was given $30 \mathrm{sec}$ to reach the platform and was allowed to remain there briefly before the $30 \mathrm{sec}$ intertrial interval.

Accuracy of performance was assessed using several measures. The primary measure was cumulative search error on training trials and a learning index score computed from the probe trials. Both measures were based on the distance of the animal from the escape platform throughout its search. Details of their computation were described previously (Gallagher et al., 1993). Briefly, the distance of the rat from the platform is sampled 10 times per second during each trial, and the distances are averaged in $1 \mathrm{sec}$ bins. Cumulative search error is the summed $1 \mathrm{sec}$ averages of this proximity measure corrected for the particular start location and platform location by subtracting the proximity score that would be produced by perfect performance on that trial. The learning index is a derived measure from average proximity (cumulative search error divided by the length of the probe trial) on the second, third, and fourth interpolated probe trials during place training. Scores from these trials are weighted and summed to provide an overall measure of spatia learning ability. Lower scores on the index indicate a more accurate search in the vicinity of the target location; higher scores indicate a more random search and poor learning. We also assessed more traditional measures of escape latency and pathlength during both place and cue training.

Behavioral data are expressed as mean \pm SEM. Two-way ANOVA (age $\times$ trial block) of the cumulative search error on training trials was used to assess spatial learning over the course of training. Age comparisons of the behavioral data were also made using one-factor ANOVAs of the learning index scores derived from the probe trials and the mean pathlengths obtained during cue training.

In this paper, the learning index is used in the statistical analyses, but at times we also refer to the performance of aged rats as "unimpaired" or "impaired." Aged-impaired rats possess learning indices larger than the range of indices for young rats, whereas aged-unimpaired rats have scores within the range of young performance.

Construction of riboprobe vectors. Using rat brain cDNA, we constructed a plasmid $\beta$ APP (p $\beta A P P$ ) containing a 382 bp PCR fragment generated from the coding region of $\beta A P P-695$ that spanned the Kunitz insert. A sense primer containing an EcoRI linker sequence (5'-TTT TGA ATT CGA GAG AAC AAC CAG CAT TG-3') and an antisense primer containing a $B a m$ HI linker sequence $\left(5^{\prime}\right.$-TTT TGG ATC CCG GCG ATC ATT GAG CAT GG-3') were used. The PCR fragment was gel-purified, hydrolyzed with the two restriction enzymes, and directionally ligated in pSELECT-1 (Promega, Madison, WI). An 830 bp section of the human Mn-SOD sequence was excised from the insert in phMnSOD4 (American Type Tissue Culture Collection; ATCC) with EcoRI, gel-purified, and ligated into pGEM3Zf $(+)$, previously linearized with EcoRI. A riboprobe for $\mathrm{Cu} / \mathrm{Zn}-\mathrm{SOD}$ was constructed by ligating a $118 \mathrm{bp}$ PCR fragment from the human sequence (ATCC) into pCRScript SK $(+)$ (Stratagene, La Jolla, CA). A sense primer (5'-ATC C TC TCA GGA GAG CAT TCC ATC ATT G-3') and an antisense primer (5'-CAA GCG GCT TCC AGC ATT TC-3') were used for the PCR. The construction of a riboprobe for b-NOS was described previously (Sugaya and McKinney, 1994). Restriction mapping and sequencing were used to confirm all constructs. A riboprobe for GFAP was a gift from Dr. D. Feinstein (Cornell University, Ithaca, NY). Control experiments demonstrated that ISHH with ${ }^{35} \mathrm{~S}$-labeled sense strands gave background signal, whereas ISHH with ${ }^{35} \mathrm{~S}$-labeled antisense strands produced appropriate signals (not shown).

Immunocytochemistry and in situ hybridization histochemistry. These procedures used fixcd, floating coronal brain sections and were performed essentially as described previously (Sugaya and McKinney, 1994) When immunostaining for GFAP was performed, it preceded ISHH and used a monoclonal antibody (Sigma, St. Louis, MO). The visualization of the antigen-antibody complexes in the brain sections was by the peroxidation of diaminobenzidine. The incubations of the brain sections with the primary and secondary antibodies, and with the avidin-biotin complex (Vector Laboratories, Burlingame, CA), were conducted in the presence of $120 \mathrm{U} / \mathrm{ml} \mathrm{RNAsin}$ (Promega). Preliminary experiments demonstrated that this concentration of the RNase inhibitor afforded ful protection of ISHH signals, equivalent to signals in sections not carried through the immunostaining procedures (data not shown). After immunostaining, the sections were transferred to buffered $4 \%$ paraformaldehydc at $4^{\circ} \mathrm{C}$ for storagc.

Most of the ISHH experiments presented in this paper were conducted using 7 young (with learning indices ranging from 133 to 228 ) and 13 aged (with learning indices ranging from 156 to 291) behaviorally characterized Long-Evans rats. After behavioral measures were complete, these sub jects were deeply anesthetized and perfused transcardially with $0.9 \%$ saline followed by buffered $4 \%$ paraformaldehyde solution, $\mathrm{pH} 7.2$. The brains were cryoprotected by $20-24 \mathrm{hr}$ of immersion in $20 \%$ sucrosecontaining fixative at $4^{\circ} \mathrm{C}$. The brains were blocked, quick-frozen on dry ice, and $25 \mu \mathrm{m}$ sections were obtained using a Leitz 1720 cryostat to obtain 12 sets of sections from each brain. The sectioning was performed by cycling between the young, aged-unimpaired, and aged-impaired groups, one at a time until all 20 brains were completely sectioned. Sections were collected in the frozen state and transferred to buffered fixative after sectioning of each subject was completed. Six of the 12 sets were immunostained for choline acetyltransferase before storage. All sections were stored in buffered $4 \%$ paraformaldehyde at $4^{\circ} \mathrm{C}$. In this condition, mRNA is stable for at least 8 weeks (our unpublished data).

Two ISHH experiments per week were performed using sections from all 20 subjects in the same experiment, with batch-prepared riboprobes. A total of 12 ISHH experiments with 11 different probes were conducted. Results from six of these ISHH experiments in the hippocampal formation and the striatum of these 20 subjects are presented in this paper. ISHH was performed with floating sections in the wells of 12-well culture plates. After $5 \mathrm{~min}$ wash of the brain sections in $0.1 \mathrm{M}$ phosphate buffer, $\mathrm{pH} 7.2$, to remove fixative, the sections were treated with proteinase $\mathrm{K}$, washed with glycine buffer, and acetylated. After a prchybridization incubation $(50 \%$ formamide, $1 \times$ Denhardt's solution, $10 \%$ dextran sul- 
fate, $4 \times \mathrm{SSC}, 0.25 \mathrm{mg} / \mathrm{ml}$ yeast tRNA, $0.3 \mathrm{mg} / \mathrm{ml}$ herring sperm DNA and $100 \mathrm{~mm}$ dithiothreitol) at $60^{\circ} \mathrm{C}$ for $1 \mathrm{hr}$, hybridization was conducted at $60^{\circ} \mathrm{C}$ for $18 \mathrm{hr}$ in a solution of the same composition but also containing $10^{6} \mathrm{cpm} / \mathrm{ml}\left[{ }^{35} \mathrm{~S}\right]$-riboprobe (except for $\beta$ APP mRNA, for which a probe concentration of $2 \times 10^{h} \mathrm{cpm} / \mathrm{ml}$ was used). Riboprobes were transcribed from the plasmids described above using a kit from Stratagene.

After the hybridization period, the sections were washed, mounted, and juxtaposed to Amersham $\beta$-max film with $\left[{ }^{14} \mathrm{C}\right]$-microscale standards (Amersham). Additional $\left[{ }^{35} \mathrm{~S}\right]$-brain paste standards were used with $\beta A P P$ ISHH because of the higher signals with this mRNA. After digitizing the films with a RELISYS 9624 scanner, National Institutes of Health Image was used to construct calibration curves with the standards and to quantitate signals from the dorsal hippocampus and dorsal striatum. Multiple measurements of these two regions were taken and averaged for each experimental subject and for each probe. Linear regression analysis was used to determine relationships between mRNA levels and the learning index, or between mRNA levels. Because all 20 subjects were assessed in the same experiment, the levels of mRNA were directly comparable between subjects. To ascertain the effect of age alone on the data, regression analysis for aged subjects separately was also performed for comparison. The majority of the data presented were from film autoradiographic analysis. For analysis at the cellular level, some sets of slides were coated with emulsion, and the silver grains overlying cellular profiles were observed and photographed using a Leitz microscope.

Three additional young (learning indices 147, 196, and 198) and five additional aged (learning indices ranged from 169-304) Long-Evans rats were used in a small study to analyze the cellular relationships between $\beta A P P$ mRNA and GFAP immunoreactivity in the hippocampus. The perfusion and preparation of brain sections was performed as described above. GFAP immunostaining was performed in the presence of RNAsin (Promega), and the sections were then carried through ISHH for $\beta$ APP mRNA. Additionally, ISHH was performed with another set of sections from these eight subjects to quantitate GFAP mRNA.

Immunoblotting experiments. The quantitation of proteins in the hippocampus and striatum was performed with a set of 20 young and aged Long-Evans rats (separate from the set used for the mRNA analyses). The learning indices for the seven young Long-Evans rats in this set ranged from 111 to 210 . The learning indices for the 13 aged subjects ranged from 174 to 314 .

To assay the proteins of interest from limited amounts of brain tissue, the best compromise of reported methods was chosen. An initial homogenization was performed without detergent, and a low-speed centrifugation was used to pellet nuclei and cell debris. The resulting supernatant is suitable for analysis of the SODs (Marklund et al., 1985; Kurobe et al., $1990 \mathrm{a}, \mathrm{b})$ and the various forms of $\beta$ APP (Beeson et al., 1994a). This supernatant contains mainly the water-soluble form of GFAP; this pool of the protein exhibited the most pronounced alterations in levels in a recent study of ischemic brain (Fahrig, 1994). Animals were killed and the brains were rapidly dissected on ice. Brain samples were frozen on dry ice and stored at $-80^{\circ} \mathrm{C}$. For homogenization, tissue was thawed on ice, gently blotted, weighed, transferred to a $1.5 \mathrm{ml}$ microfuge tube, and minced in $4-5$ vol of cold stabilization buffer containing: 5 mM HEPES, pH $8,0.32$ M sucrose, $5 \mathrm{~mm}$ benzamidine, $2 \mathrm{~mm} \beta$-mercaptoethanol, 3 mм EGTA, 2 $\mathrm{mm}$ phenylmethylsulfonyl fluoride, $0.5 \mathrm{~mm}$ magnesium sulfate, $0.01 \mathrm{~mm}$ sodium metavanadate, $0.05 \%$ sodium azide, $10 \mathrm{ng} / \mathrm{ml}$ aprotinin, $10 \mathrm{ng} / \mathrm{ml}$ pepstatin $\mathrm{A}$, and $100 \mathrm{ng} / \mathrm{ml}$ leupeptin. The mince was homogenized on ice, and cell debris was pelleted at $3000 \times g$ for $10 \mathrm{~min}$ at $4^{\circ} \mathrm{C}$. The pellets were frozen at $-80^{\circ} \mathrm{C}$. Protein determinations of the supernatant were performed in triplicate using a kit from Bio-Rad (Hercules, CA). Ilippocampal and striatal extracts yielded mean protein concentrations of $6.50 \pm 0.72$ and $8.24 \pm 0.89 \mathrm{mg} / \mathrm{ml}$, respectively.

Protein analysis by sodium dodecyl sulfate-polyacrylamide gel electrophoresis was performed using previously established methods (Laemmli, 1970; Towbin et al., 1979). Gels with a $4-20 \%$ gradient, or 12.5 and $15 \%$ acrylamide concentrations, were used for $\beta$ APP, GFAP, and SODs, respectivcly. Western blotting experiments used $50-80 \mu \mathrm{g}$ total protein per well. Samples were treated with equal volumes of Laemmli $2 \times$ sample buffer, mixed and placed in a $95^{\circ} \mathrm{C}$ water bath for 10 min. All samples were adjusted to equal sample volumes $(20-40 \mu \mathrm{I})$ with $1 \times \mathrm{Laemml}$ sample buffer, vortexed, and centrifuged briefly at $7000 \times \mathrm{g}$. Conditions for the most complete transfer of proteins to nitrocellulose were gauged by the post-transfer densitometric analysis of gels for residual prestaincd or Coomassie-stained molecular weight standards relative to the signal intensity for those proteins in unblotted gels and relative to Western blotted mature, glycosylated $\beta$ APP (103-120 kDa forms). Optimum transfer was empirically determined by varying the percentages of methanol and SDS, with the most efficient transfer observed at 5\% methanol, $0.01 \%$ SDS in Towbin transfer buffer (modified Towbin transfer buffer). For $\beta A P P$, aqueous transfer was performed at $1 \mathrm{~A}$ with $2-4$ gels per transfer tank using 11 of modified Towbin transfer buffer at $4^{\circ} \mathrm{C}$. Semidry transfer was performed for $1-1.5 \mathrm{hr}, 1.25 \mathrm{~A}$ per gel at $4^{\circ} \mathrm{C}$ in Towbin transfer buffer (SOD) or modified Towbin transfer buffer (GFAP).

After transfer of protein to nitrocellulose, membranes were blocked overnight at $4^{\circ} \mathrm{C}$ in Tris-buffered saline (TBS) containing $0.075 \%$ Tween-20 and augmented with $4 \%$ preimmune goat serum. Blots were washed in TBS, pH 7.5, and transferred to blocking buffer containing the primary antibody. To detect $\beta$ APP, primary antibody incubation was performed for 3-5 hr using a mouse monoclonal antibody $(10 \mu \mathrm{g} / \mathrm{ml}$; antibody 22C11; Boehringer Mannheim, Indianapolis, IN), which recognizes an empirically identified epitope between residues $66-81$ of $\beta A P P$ (Hilbich et al., 1993). Although commonly used for immunoblotting of $\beta A P P$, this antibody has been shown recently to cross-react with amyloid protcin-like protein 2 (APLP2) (Slunt et al., 1994). Therefore, the signals produced with $22 \mathrm{C} 11$ are more correctly interpreted as " $\beta$ APP-like" immunoreactivity, and detailed characterization of this family of similar proteins will require the use of selective antibodies for $\beta A P P$ as well as for the APLPs.

Primary antibody incubation for GFAP was performed for $2 \mathrm{hr}$ using a mouse monoclonal anti-pig GFAP (1:400 dilution; Sigma). Purified rabbit anti-rat $\mathrm{Mn}$ - and $\mathrm{Cu} / \mathrm{Zn}$-SOD antibodies were generous gifts from $\mathrm{Dr}$. $\mathrm{K}$. Kato (Department of Biochemistry, Institute for Developmental Rescarch, Aichi Perfectural Colony, Kamiya, Kasugai, Aichi 480-03, Japan) (Kato et al., 1995). Primary antibody incubation was performed at 2 $\mu \mathrm{g} / \mathrm{ml} \mathrm{IgG} \mathrm{concentration} \mathrm{for} 2 \mathrm{hr}$. The primary immunoreaction was conducted at room temperature and was terminated by three successive washes in TBS. Blots subjected to monoclonal immunoprobes were incubated in TBS containing a 1:5000 dilution of goat anti-mouse IgG (whole antibody) conjugated to alkaline phosphatase (Pierce, Rockford, IL). Blots using polyclonal primary immunoprobes were subjected to a similar alkaline phosphatase conjugate specific for rabbit heavy and light chain IgG at a 1:5000 dilution for $1 \mathrm{hr}$ at room temperature. Western blots were run with prestained molecular weight markers (Novex, San Diego, $\mathrm{C} \Lambda$ ) to verify electrophoretic migration and transfer cfficicncy. Biotinylated markers (Bio-Rad, Hercules, CA) were also used and were revealed with streptavidin-coupled alkaline phosphatase (Pierce) after densitometric analysis of immunoblots. Immunoreactivity was revealed using nitroblue tetrazolium and BCIP alkaline phosphatase substrates.

In slot-blotting experiments, we observed a linear immunoreactive response from 5 to $80 \mu \mathrm{g}$ of total protein per well for GFAP, $\beta A P P$, $\mathrm{Mn}-\mathrm{SOD}$, and $\mathrm{Cu} / \mathrm{Zn}-\mathrm{SOD}$ in preliminary experiments with rat striatal tissue. Protein samples were diluted $\sim 20$-fold in cold $0.5 \times$ stabilization buffer and distributed to samplc wells in $100 \mu$ l aliquots.

\section{RESULTS}

\section{Behavioral analyses}

Behavioral testing revealed a significant effect of age on performance in the water maze during spatial learning but no age difference during nonspatial cue learning. Figure 1 depicts the difference in performance over the course of training in the spatial task between the young and aged groups of rats used in the two major studies (ISHH for mRNA and immunoblotting for proteins). A significant mean effect of age was revealed in a two-way ANOVA (age $\times$ block) of the cumulative search error $\left(F_{(1,38)}=\right.$ $26.35 ; p<0.0001)$. Although the age groups did not differ on the first training trial, young rats became proficient in the task more readily than the aged rats. In contrast to the age-related impairment during spatial learning trials, no age difference was evident during cue training (average pathlength to the escape platform was $209 \pm 21.4$ for young and $225 \pm 18.9$ for aged groups). Young animals also exhibited a more rapid acquisition of a spatial bias during probe trials (Fig. 2). Learning indices for young and aged subjects are compared in Figure 2, in which data for the rats used for the mRNA assessments are shown on the left, and data for the rats used in the protein measurements are shown on the right. The young rats, on average, had better spatial learning index scores 


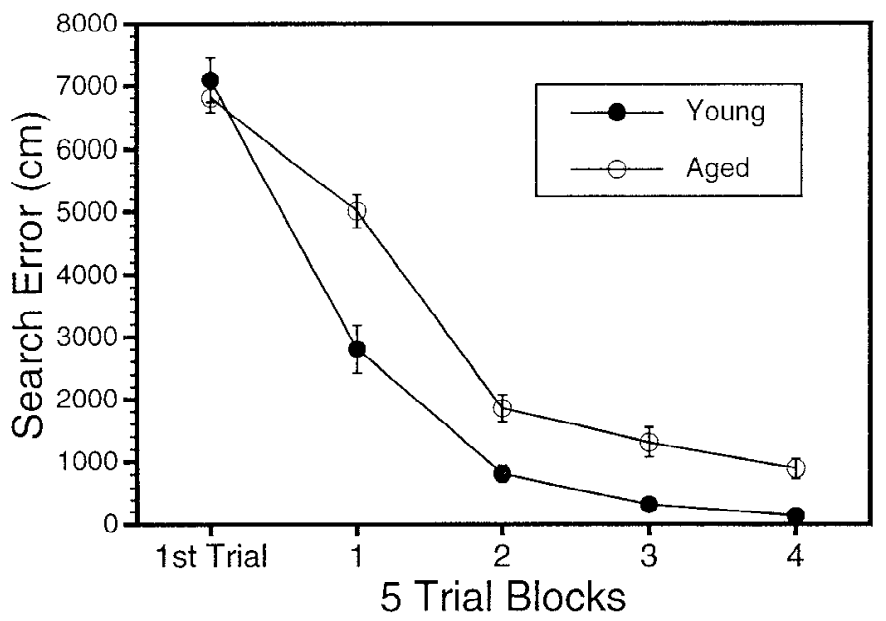

Figure 1. Behavioral characterization of young and aged Long-Evans rats used in the two primary studies (ISHH, $n=20$; protein immunoblotting, $n=20$ ). Pcrformance (cumulative search crror) is plotted versus the number of the training trial block. The two curves represent average performances of the young rat $(n=14, \boldsymbol{\bullet})$ and the aged rats $(n-26,0)$.

(lower values) compared with the aged rats. In both sets of rats, this difference was statistically reliable $\left[F_{(7,13)}=14.07, p<0.002\right.$ and $F_{(7,13)}=14.73, p<0.005$ for the ISHH and protein analysis data sets, respectively]. Note, however, the considerable individual differences exhibited by aged rats, with a subpopulation of aged rats exhibiting learning ability within the range of values for the young rats ("aged-unimpaired"), whereas the scores for the other aged cohorts fall entirely outside the range of young performance ("aged-impaired").

\section{Assessment of mRNA for BAPP in the hippocampus of young and aged Long-Evans rats}

The various isoforms of $\beta A P P$ can be viewed as potential neuronal plasticity markers in the aging brain; $\beta$ APP may also be a sensitive indicator of oxidative stress conditions. The riboprobe we developed for quantitating $\beta A P P$ mRNA in the brain hybrid izes to all three major forms of $\beta$ APP mRNA, i.e., those coding for $\beta$ APP- 695 , $\beta$ APP-750, and $\beta$ APP-771. However, the majority of $\beta A P P$ signal in brain tissue arises from $\beta A P P-695$, and this is thought to be expressed mainly in neurons (Beeson et al., 1994a). To assess the effects of aging on the expression of $\beta$ APP mRNA in the hippocampal formation, 20 young and aged subjects were probed in the same experiment. Representative film autoradiographs of the hippocampal region are presented in the top set of images in Figure 3, which correspond to a young, an agedunimpaired, and an aged-impaired rat. This ISHH experiment showed that, in the hippocampus considered as a whole, the level of mRNA for the aggregate of $\beta$ APP species was significantly elevated in a way positively correlated with the learning index. The average levels of mRNA signal in the whole dorsal hippocampus from all 20 subjects, measured from digitized film autoradiographs using National Institutes of Health Image, are plotted versus the learning index in Figure 4 (left column). The correlation coefficient $(r)$ for the these $\beta$ APP mRNA data was 0.53 , which was statistically significant $(n=20 ; p<0.05)$. Because of variability in the data set, the correlation between $\beta A P P$ mRNA and learning index was no longer reliable when only the aged rats were analyzed ( $r=0.18$; Table 1$)$. As is apparent in Figure 4, this could be because of a high $\beta$ APP value for one of the aged subjects, one with a learning index (156) lower than all but one of the young rats. Without this aged subject, the $r$ value for the $\beta$ APP learning index correlation for the remaining aged subjects $(n=12)$ was 0.45 , similar in magnitude to the $r$ value for the full data set.

Previously, using a method of mRNA quantitation using RT/ PCR and competition with a mutant $\beta A P P$ sequence, we found that aged-impaired Long-Evans rats expressed higher levels (624 $\pm 133 \mathrm{fg} / \mathrm{mg}$ total RNA; $n=11$ ) of $\beta$ APP-695 than did agedunimpaired subjects ( $313 \pm 42 \mathrm{fg} / \mathrm{mg}$ total RNA; $n=11$ ) (Greene et al., 1992). In the same study, no change in $\beta A P P-751$ or $\beta A P P-770$ were found using Southern blotting methods. Thus, in the present study, the elevation of $\beta$ APP mRNA in the aged brain probably reflects a selective change in $\beta A P P-695$ mRNA expression.

\section{Alteration of mRNA for GFAP in the hippocampus}

The astrocyte marker GFAP is well known to be altered in response to a variety of brain insults. This marker is also reported to be increased in several aging studies. Our film autoradiographs of the hippocampus of young and aged Long-Evans rats revealed a strong upregulation of GFAP mRNA (see Fig. 3 for representative digitized autoradiographs). This marker was expressed at relatively high levels in the glia limitans, but also in both the internal gray matter and the white matter of the hippocampus. In a regression analysis using film data for the whole hippocampus for all 20 of the young and aged subjects, this increase was observed to be significantly and positively related to the learning index $(r=0.83 ; p<0.001$; Fig. 4 , Table 1$)$. Furthermore, GFAP mRNA levels in the hippocampus remained significantly and positively correlated with the learning index when only aged subjects were analyzed $(r=0.67 ; p<0.05$; Table 1$)$. Interestingly, even the group of young rats alone $(n=7)$ exhibited a correlation between GFAP mRNA and the learning index $(r=0.81$; $p<0.05$ ).

\section{Quantitation of mRNAs for b-NOS and the SODs in the hippocampus}

The mRNAs for b-NOS and the two SODs were studied in the hippocampus of these 20 young and aged Long-Evans rats using

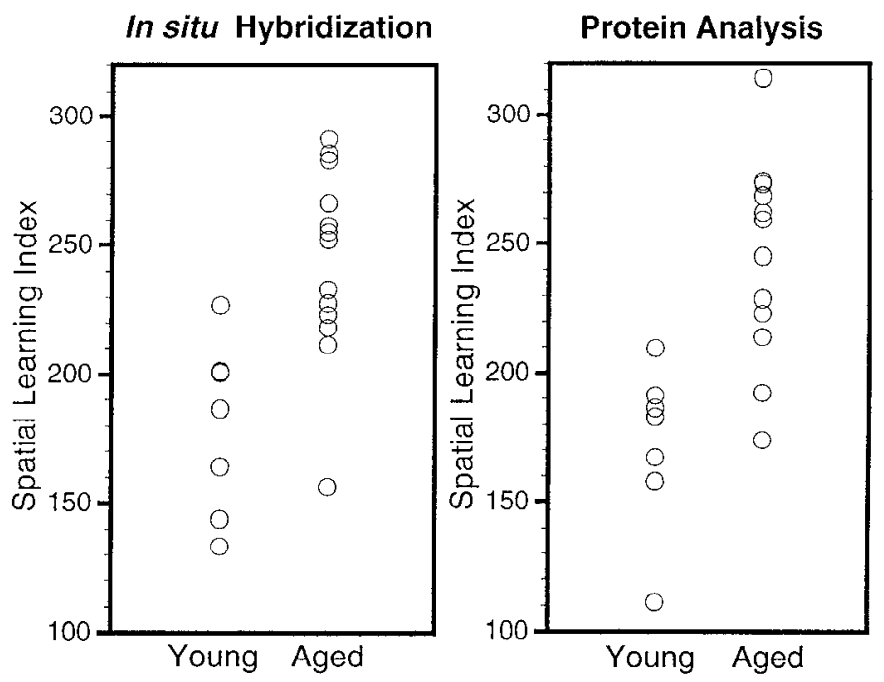

Figure 2. Spatial learning indices computed from probe trial performances. The data are plotted as scattergrams, with the data for the young and aged subjects used in the ISIIII experiments shown in the left plot; and the data for the young and aged subjects used in the protein immunoblotting experiments shown in the right plot. The $y$-axes are scales of the learning indices calculated as described in Materials and Methods. 
Young

(a) APP

(b) GFAP

(c) Mn-SOD

(d) $\mathrm{Cu} / \mathrm{Zn}-\mathrm{SOD}$
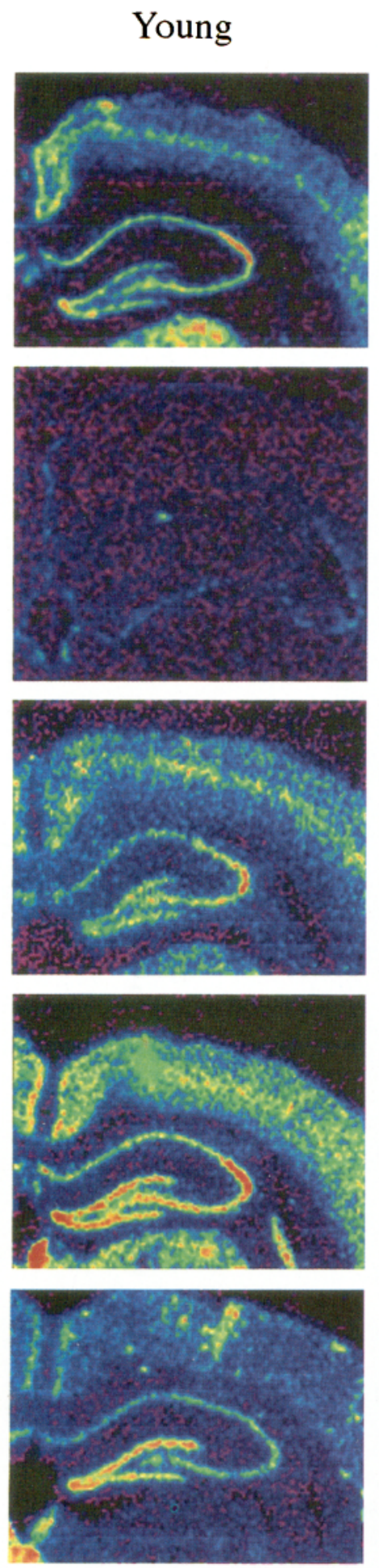

Aged
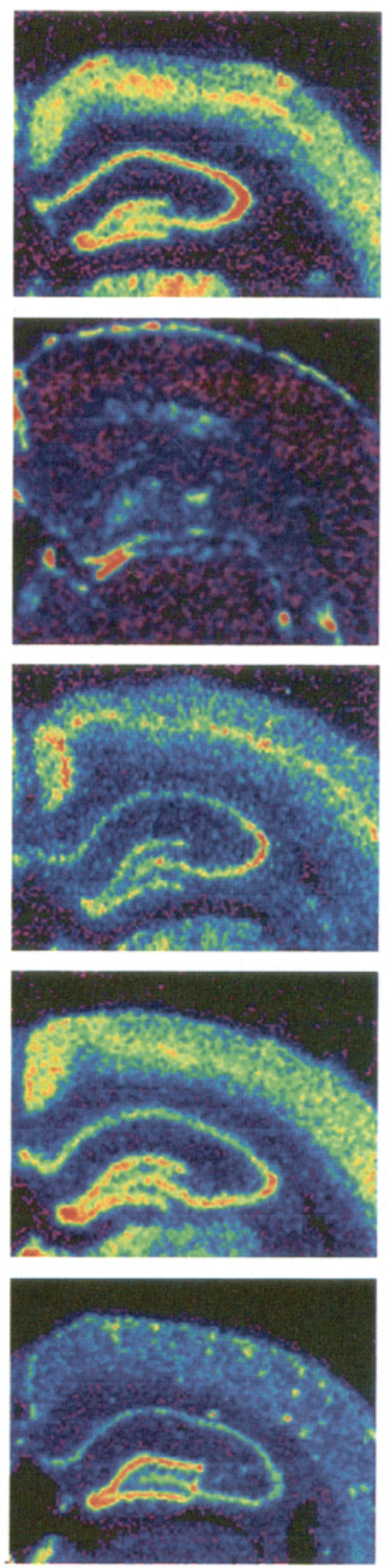

\section{Aged-Impaired}
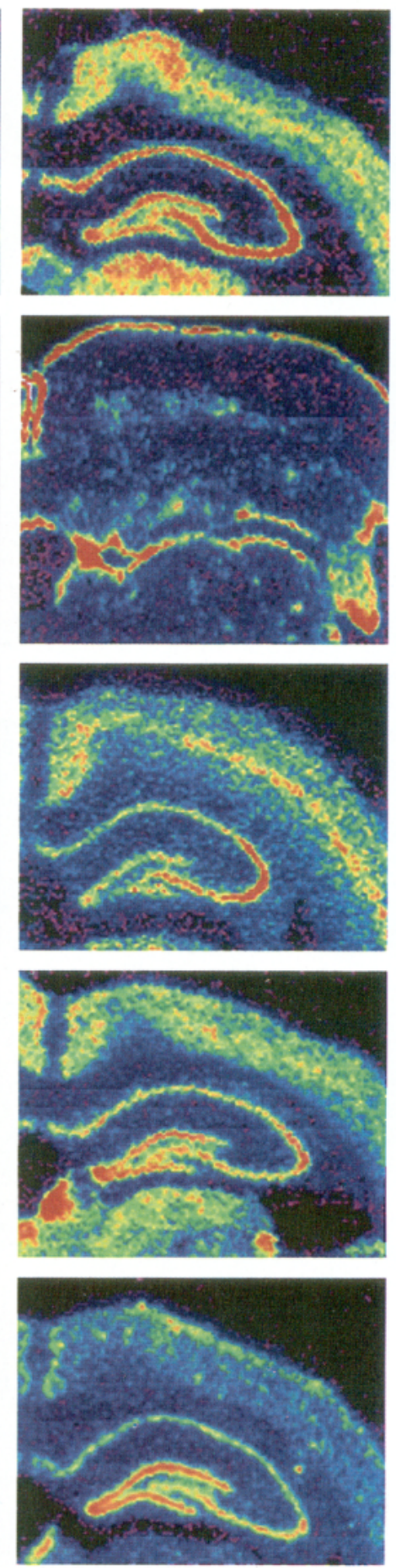

Figure 3. Digitized autoradiographs of representative young, aged-unimpaired, and aged-impaired subjects from ISHH experiments for $\beta$ APP (APP), $M n$-SOD, GFAP, $b-N O S$, and $C u / Z n$-SOD mRNAs. These images were scanned into the computer at actual size and quantitated using National Institutes of Health Image. The subjects were selected based on the proximity of their averages to the linear regression lines shown in Figure 4 for the hippocampal analyses. Warmer colors represent higher levels of mRNA. All images were normalized to a common set of values for the $\left[{ }^{14} \mathrm{C}\right]$ standards.

quantitative ISHH methods. Digitized film autoradiographs of the hippocampal region for b-NOS, Mn-SOD, and $\mathrm{Cu} / \mathrm{Zn}-\mathrm{SOD}$ mRNA in three representative subjects (young, aged-unimpaired rat, and aged-impaired) are shown in Figure 3. The mRNA for b-NOS is expressed at relatively high levels in pyramidal and granule cells of the hippocampal formation, as well as in scattered cells outside of these layers (Sugaya and McKinney, 1994). The level of b-NOS mRNA in the hippocampus was observed to be positively correlated with the learning index $(r=0.46 ; p<0.05$; Fig. 4). The regression was not reliable statistically when only aged rats were considered in the analysis, but the magnitude of the correlation coefficient was nearly the same $(r=0.42 ; p>0.05)$. 

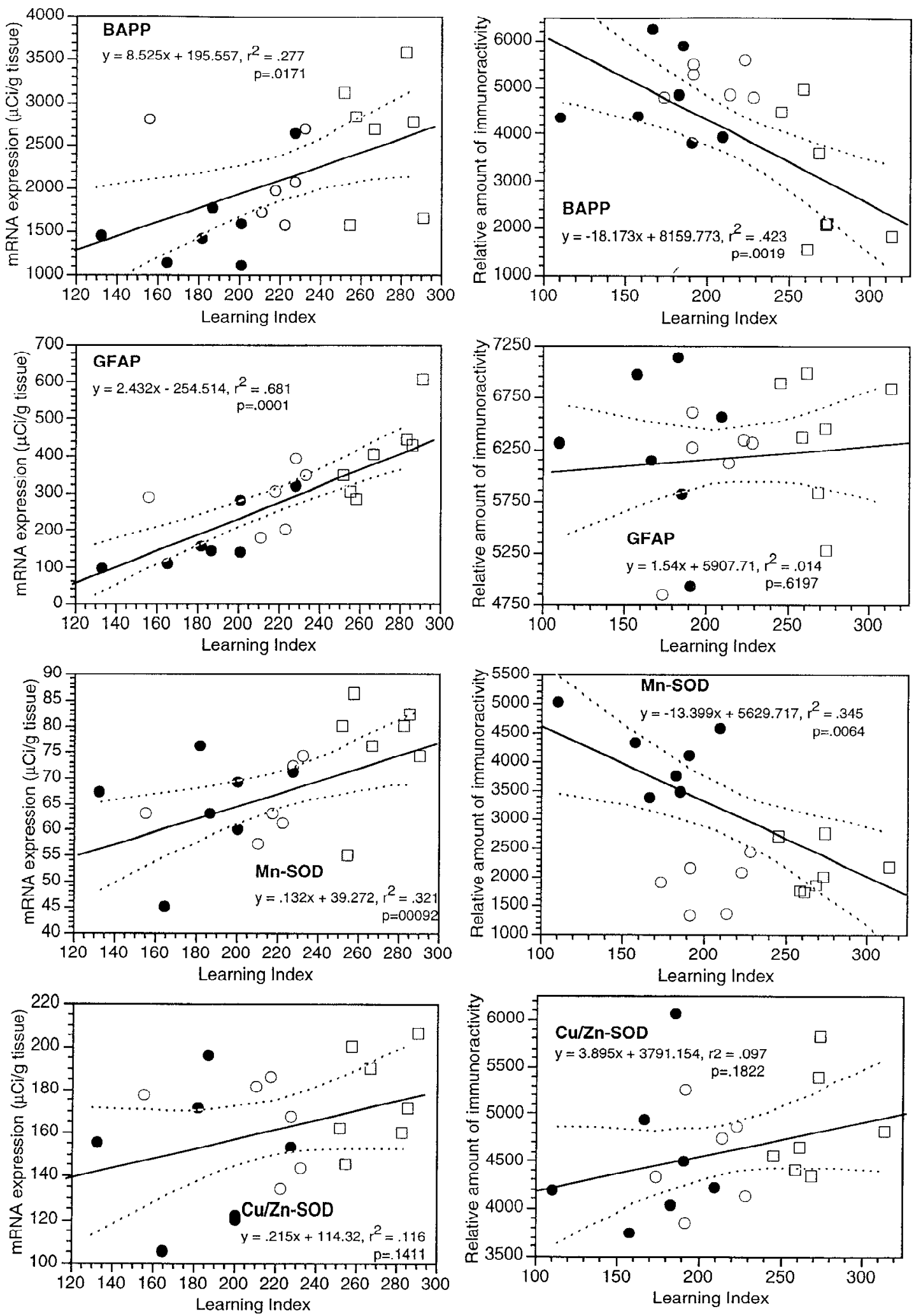

Figure 4. Levels of mRNA (left column) and corresponding proteins (right column) in the dorsal hippocampus of young and aged Long-Evans rats, plotted versus the learning index. Twenty rats were used in the ISHH experiments ( 7 young and 13 aged), and another 20 rats were used for protein analyses. The data for young rats are plotted as filled symbols, and the aged rats are shown as open symbols. The aged subjects are further delineated as "aged-unimpaired" (open circles), or "aged-impaired" (open squares), according to whether their learning index was within the range of the young rats. The mRNA data were sampled using National Institutes of Health Image from scanned film autoradiographs, and each point is the average of levels in the hippocampus for several samples of each subject. The mRNA levels are calibrated according to the tissue equivalents determined from $\left[{ }^{14} \mathrm{C}\right]$ standards exposed on the films and corrected for film background. The levels of proteins were determined in hippocampal extracts by slot blotting; the levels shown are relative optical densities taken from scanned blots using the program National Institutes of Hcalth Image. The $x$-axis is the scalc of the Icarning indices, with better performance in the spatial task at the left end and poorer performance at the right end. 


\begin{tabular}{|c|c|c|c|c|c|}
\hline Marker & $\beta A P P$ & GFAP & Mn-SOD & $\mathrm{Cu} / \mathrm{Zn}-\mathrm{SOD}$ & b-NOS \\
\hline \multicolumn{6}{|c|}{ Analysis of data for all rats together $($ young $=7 ;$ aged $=13$ ) } \\
\hline$\beta A P P$ & & $0.57^{* *}$ & $0.69^{* * *}$ & 0.37 & $0.51^{*}$ \\
\hline GFAP & & & $0.58 * *$ & 0.43 & $0.67^{* *}$ \\
\hline $\mathrm{Mn}-\mathrm{SOD}$ & & & & $0.49 *$ & $0.58^{* *}$ \\
\hline $\mathrm{Cu} / \mathrm{Zn}-\mathrm{SOD}$ & & & & & $0.58^{* *}$ \\
\hline \multicolumn{6}{|l|}{ b-NOS } \\
\hline Learning index & $0.53^{*}$ & $0.83^{* * *}$ & $0.56^{* *}$ & 0.34 & $0.46^{*}$ \\
\hline Marker & $\beta A P P$ & GFAP & Mn-SOD & $\mathrm{Cu} / \mathrm{Zn}-\mathrm{SOD}$ & b-NOS \\
\hline \multicolumn{6}{|c|}{ Analysis of data for aged rats only $(n=13)$} \\
\hline$\beta A P P$ & & 0.21 & $0.73^{* *}$ & 0.03 & 0.32 \\
\hline GFAP & & & 0.54 & 0.37 & $0.79 * *$ \\
\hline $\mathrm{Mn}-\mathrm{SOD}$ & & & & 0.31 & 0.47 \\
\hline $\mathrm{Cu} / \mathrm{Zn}-\mathrm{SOD}$ & & & & & 0.31 \\
\hline \multicolumn{6}{|l|}{ b-NOS } \\
\hline Learning index & 0.18 & $0.67^{*}$ & $0.60^{*}$ & 0.16 & 0.42 \\
\hline
\end{tabular}

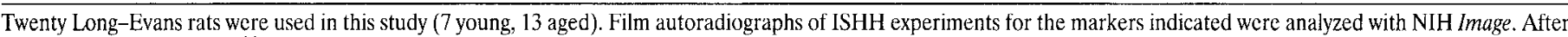

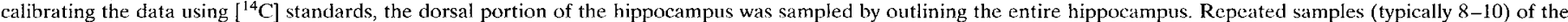

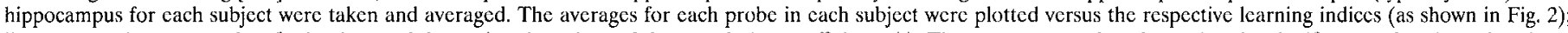

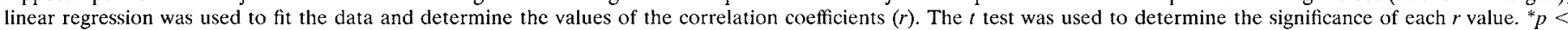
$0.05 ;{ }^{*} p<0.01 ;{ }^{* * *} p<0.001$

With regard to the mRNAs for the two antioxidant enzymes studied, the film autoradiographic data revealed that the mRNA for the Mn-SOD was increased in the whole hippocampus in a positive relationship with the learning index $(r=0.56 ; p<0.01$; Fig. 4; representative autoradiographs are shown in Fig. 3, and correlation coefficients are summarized in Table 1), whereas the level of mRNA for $\mathrm{Cu} / \mathrm{Zn}$-SOD was not significantly correlated with the learning impairment ( $p>0.05$; Figs. 3,4 , Table 1$)$. The lcvel of $\mathrm{Cu} / \mathrm{Zn}-\mathrm{SOD}$ mRNA was similarly unrelatcd to the lcarning index in every other brain region examined (data not shown). The significant positive correlation between Mn-SOD mRNA and the learning index was retained in the group consisting of only the aged rodents $(r=0.60 ; p<0.05$; Table 1$)$.

\section{Correlations between mRNA markers in the hippocampus}

As summarized in the top of Table 1, the level of $\beta A P P$ mRNA in the whole dorsal hippocampus of the composite group of 20 young and aged rats was correlated with the levels of GFAP, Mn-SOD, and b-NOS mRNAs. Similarly, the level of b-NOS mRNA was correlated with GFAP, Mn-SOD, and $\mathrm{Cu} / \mathrm{Zn}-\mathrm{SOD}$ mRNA levels. As well, the levels of Mn-SOD mRNA and $\mathrm{Cu} / \mathrm{Zn}-\mathrm{SOD}$ mRNA in the hippocampus were positively correlated with each other. When only aged subjects were analyzed ( $n=13$; bottom of Table $1)$, most of these correlations between markers lost statistical significance. However, the correlation between $\beta A P P$ and $\mathrm{Mn}-\mathrm{SOD}$ mRNAs was retained and even increased in magnitude $(r=0.73 ; p<0.01)$. Additionally, the correlation between $b-N O S$ and GFAP mRNA levels was significant in the aged cohort $(r=0.79 ; p<0.01)$.

\section{Regional and cellular quantitation of mRNAs in the hippocampal formation}

Several of the markers we studied are strongly expressed in the pyramidal and granule cell layers in the hippocampal formation, making it possible to obtain measures of these markers within well-defined anatomical boundaries using film autoradiographs. The results for $\beta$ APP, b-NOS, Mn-SOD, and $\mathrm{Cu} / \mathrm{Zn}$-SOD mRNA molecules measured within the pyramidal cell layer of the $\mathrm{CA} 1$, $\mathrm{CA} 2, \mathrm{CA} 3$, and hilar regions, and in granule cell layers within each blade of the dentate gyrus in the dorsal hippocampus, are presented in Tables 2 (all subjects) and 3 (aged subjects only).

In the combined set of young and aged rats, significant correlations between BAPP mRNA and learning index were observed in four of the six regions analyzed (Table 2). Mn-SOD mRNA was correlated with the learning index in two of the six regions quantitated: the CA2 pyramidal cell layer $(r=0.48 ; p<0.05)$ and the granule cells in the inferior blade of the dentate gyrus $(r=0.50 ; p<0.05)$. The level of b-NOS mRNA was significantly correlated with the learning index in the granule cell layer of the inferior blade of the dentate gyrus $(r=$ $0.45 ; p<0.05$ ). $\beta$ APP mRNA was significantly and positively correlated with the other three mRNAs in the CA1 region and in the inferior blade of the dentate gyrus, whereas b-NOS mRNA was correlated with the mRNAs for both of the SODs in the granule cell layers of the dentate gyrus.

With the exception of Mn-SOD mRNA in the CA2 and CA3 regions, none of the four mRNA markers was correlated with the learning index in any of the six hippocampal regions when only the aged rats were analyzed (Table 3 ). In the aged hippocampus, b-NOS and $\beta A P P$ mRNAs remained correlated in four of the six divisions, and Mn-SOD mRNA exhibited correlationships with $\beta A P P$ (in CA3 and hilus) and b-NOS mRNA (in hilus and dentate gyrus).

The expression of $\beta A P P$ mRNA at the cellular level in the hippocampus was studied by emulsion-coating the sections analyzed above by film autoradiographs. A comparison between two aged individuals is shown in Figure 6. A section from an aged-unimpaired rat (learning index $=218$ ) is shown in the top panel, and a section from an aged-impaired rat (learning index $=286$ ) is shown in the bottom panel. These two subjects were chosen as representative of the two behavioral classes based on the proximity of their $\beta A P P$ measures in film autoradiographs to the regression line shown in Figure 4. Strong increases in $\beta$ APP signal in the pyramidal and granule cell layers are evident in this comparison. The hilus exhibits 


\begin{abstract}
Table 2. Correlations between mRNAs, and between mRNA and the learning index, in six regions of the hippocampal formation of 20 young and aged Long-Evans rats
\end{abstract}

\begin{tabular}{|c|c|c|c|c|}
\hline Marker & $\beta \mathrm{APP}$ & b-NOS & $\mathrm{Mn}-\mathrm{SOD}$ & $\mathrm{Cu} / \mathrm{Zn}-\mathrm{SOD}$ \\
\hline \multicolumn{5}{|c|}{ CA1 pyramidal cell layer } \\
\hline$\beta A P P$ & & $0.48^{*}$ & $0.64 * *$ & $0.62 * *$ \\
\hline b-NOS & & & $0.62^{* *}$ & 0.32 \\
\hline $\mathrm{Mn}-\mathrm{SOD}$ & & & & $0.44^{*}$ \\
\hline Learning index & $0.54^{*}$ & 0.21 & 0.42 & 0.25 \\
\hline Marker & $\beta \mathrm{APP}$ & b-NOS & Mn-SOD & $\mathrm{Cu} / \mathrm{Zn}-\mathrm{SOD}$ \\
\hline \multicolumn{5}{|c|}{ CA2 pyramidal cell layer } \\
\hline$\beta A P P$ & & 0.42 & $0.56^{* *}$ & 0.39 \\
\hline b-NOS & & & 0.31 & 0.39 \\
\hline $\mathrm{Mn}-\mathrm{SOD}$ & & & & $0.46^{*}$ \\
\hline Learning index & $0.56^{*}$ & 0.05 & $0.48^{*}$ & 0.38 \\
\hline Marker & $\beta A P P$ & b-NOS & Mn-SOD & $\mathrm{Cu} / \mathrm{Zn}-\mathrm{SOD}$ \\
\hline
\end{tabular}

\begin{tabular}{|c|c|c|c|c|}
\hline \multicolumn{5}{|c|}{ CA3 pyramidal cell layer } \\
\hline$\beta A P P$ & & $0.51^{*}$ & $0.57^{* * *}$ & 0.43 \\
\hline b-NOS & & & $0.53^{*}$ & 0.29 \\
\hline $\mathrm{Mn}-\mathrm{SOD}$ & & & & 0.38 \\
\hline Learning index & 0.44 & 0.11 & 0.21 & 0.32 \\
\hline Marker & $\beta A P P$ & b-NOS & Mn-SOD & $\mathrm{Cu} / \mathrm{Zn}-\mathrm{SOD}$ \\
\hline \multicolumn{5}{|l|}{ Hilus } \\
\hline$\beta A P P$ & & $0.66^{* *}$ & $0.59 * *$ & 0.36 \\
\hline b-NOS & & & $0.57^{* *}$ & 0.15 \\
\hline Mn-SOD & & & & 0.36 \\
\hline Learning index & 0.31 & 0.06 & 0.27 & 0.2 \\
\hline Marker & $\beta A P P$ & b-NOS & $\mathrm{Mn}-\mathrm{SOD}$ & $\mathrm{Cu} / \mathrm{Zn}-\mathrm{SOD}$ \\
\hline
\end{tabular}

Granule cells of the upper blade of the dentate gyrus

\begin{tabular}{lllll}
$\beta$ APP & & $0.76^{* * *}$ & $0.61^{* *}$ & 0.32 \\
b-NOS & & & $0.71^{* * *}$ & $0.53^{*}$ \\
Mn-SOD & & & & $0.59^{* *}$ \\
Learning index & $0.52^{*}$ & 0.35 & 0.35 & 0.2 \\
\hline Marker & \multirow{2}{*}{$\beta$ AAPP } & b-NOS & Mn-SOD & Cu/Zn-SOD
\end{tabular}

Granule cells of the lower blade of the dentate gyrus

$\begin{array}{lllll}\beta \text { APP } & & 0.81^{* * *} & 0.59^{* *} & 0.54^{*} \\ \text { b-NOS } & & & 0.67^{* *} & 0.54^{*} \\ \text { Mn-SOD } & & & & 0.57^{* *} \\ \text { Learning index } & 0.47^{*} & 0.45^{*} & 0.50^{*} & 0.24\end{array}$

Using calibrated film autoradiographs, the pyramidal and granule cell layers in the indicated regions of the dorsal hippocampal formation were repeatedly sampled (typically 8-10 for each subject). Linear regression was used to obtain the $r$ values for correlations. Levels of significance: ${ }^{*} p<0.05 ;{ }^{* *} p<0.01 ;{ }^{* * *} p<0.001$.

a very noticeable increase in signal in this comparison (see Fig. 6), but the data in Tables 1-3 did not reveal a significant correlation between $\beta$ APP and learning index in either the whole hippocampus or within a hippocampal region in the aged cohort. However, as we stated above, we reexamined the $\beta A P P$ data and found that a single aged subject (learning index $=156$ ) was an outlier: analysis without this outlicr indicated that $\beta$ APP mRNA was significantly increased in level in the hippocampus, including in the hilar region, of agedimpaired rats. Thus, the ISHH data shown in Figure 5 are typical of 12 of the 13 aged subjects we studied.
Table 3. Correlations between mRNAs, and between mRNA and the learning index, in six regions of the hippocampal formation of aged Long-Evans rats only $(n=13)$

\begin{tabular}{|c|c|c|c|c|}
\hline Marker & $\beta A P P$ & b-NOS & Mn-SOD & $\mathrm{Cu} / \mathrm{Zn}-\mathrm{SOD}$ \\
\hline \multicolumn{5}{|c|}{ CA1 pyramidal cell layer } \\
\hline$\beta A P P$ & & 0.4 & 0.53 & 0.52 \\
\hline b-NOS & & & 0.51 & 0.05 \\
\hline Mn-SOD & & & & 0.18 \\
\hline Learning index & 0.24 & 0.2 & 0.51 & 0.03 \\
\hline Marker & $\beta A P P$ & b-NOS & Mn-SOD & $\mathrm{Cu} / \mathrm{Zn}-\mathrm{SOD}$ \\
\hline \multicolumn{5}{|c|}{ CA2 pyramidal cell layer } \\
\hline$\beta A P P$ & & 0.49 & 0.44 & 0.17 \\
\hline b-NOS & & & 0.19 & -0.04 \\
\hline $\mathrm{Mn}-\mathrm{SOD}$ & & & & 0.34 \\
\hline Learning index & 0.28 & 0.22 & $0.62^{*}$ & 0.24 \\
\hline Marker & $\beta A P P$ & b-NOS & $\mathrm{Mn}-\mathrm{SOD}$ & $\mathrm{Cu} / \mathrm{Zn}-\mathrm{SOD}$ \\
\hline \multicolumn{5}{|c|}{ CA3 pyramidal cell layer } \\
\hline$\beta A P P$ & & $0.77^{* *}$ & $0.61^{*}$ & 0.39 \\
\hline b-NOS & & & 0.55 & 0.28 \\
\hline Mn-SOD & & & & 0.4 \\
\hline Learning index & 0.28 & 0.28 & $0.57^{*}$ & 0.36 \\
\hline Marker & $\beta \mathrm{APP}$ & b-NOS & Mn-SOD & $\mathrm{Cu} / \mathrm{Zn}-\mathrm{SOD}$ \\
\hline \multicolumn{5}{|l|}{ Hilus } \\
\hline$\beta A P P$ & & $0.78^{* *}$ & $0.6^{*}$ & 0.34 \\
\hline b-NOS & & & $0.69^{* *}$ & 0.12 \\
\hline Mn-SOD & & & & 0.34 \\
\hline Learning indcx & 0.15 & 0.3 & 0.53 & 0.13 \\
\hline Marker & $\beta A P P$ & b-NOS & $\mathrm{Mn}-\mathrm{SOD}$ & $\mathrm{Cu} / \mathrm{Zn}-\mathrm{SOD}$ \\
\hline
\end{tabular}

Granule cells of the upper blade of the dentate gyrus

\begin{tabular}{lllll}
$\beta$ APP & & $0.6^{*}$ & 0.46 & 0.21 \\
b-NOS & & & $0.57^{*}$ & 0.37 \\
Mn-SOD & & & & 0.38 \\
Learning index & 0.19 & 0 & 0.43 & 0.03 \\
& & & & \\
Marker & \multirow{2}{*}{$\beta$ APP } & b-NOS & Mn-SOD & \multirow{2}{*}{$\mathrm{Cu} / \mathrm{Zn}$-SOD } \\
\hline
\end{tabular}

Granule cells of the lower blade of the dentate gyrus

$\begin{array}{lllll}\beta A P P & & 0.68^{* * *} & 0.36 & 0.38 \\ \text { b-NOS } & & & 0.42 & 0.31 \\ \text { Mn-SOD } & & & & 0.23 \\ \text { Learning index } & 0.08 & 0.11 & 0.5 & 0.12\end{array}$

Using calibrated film autoradiographs, the pyramidal and granule cell layers in the indicated regions of the dorsal hippocampal formation were repeatedly sampled (typically 8-10 for each subject). Linear regression was used to obtain the $r$ values for correlations. Levels of significance: ${ }^{*} p<0.05 ;{ }^{* *} p<0.01 ;{ }^{* * *} p<0.001$,

To examine further the question of cellular identities for the $\beta A P P$ mRNA increases in aged-impaired Long-Evans rats, sections from several additional young and aged rat brains were immunostained for GFAP before performing ISHH for $\beta$ APP mRNA. The film autoradiographic data were used to select two subjects at each end of the range of the learning index, one young rat (learning index $=196$ ) and one aged-impaired rat (learning index $=269$ ). Photomicrographs of several regions of the hippocampal formation of these two subjects are compared in Figure 7 . In both the young and aged subjects, the $\beta$ APP mRNA signal is 

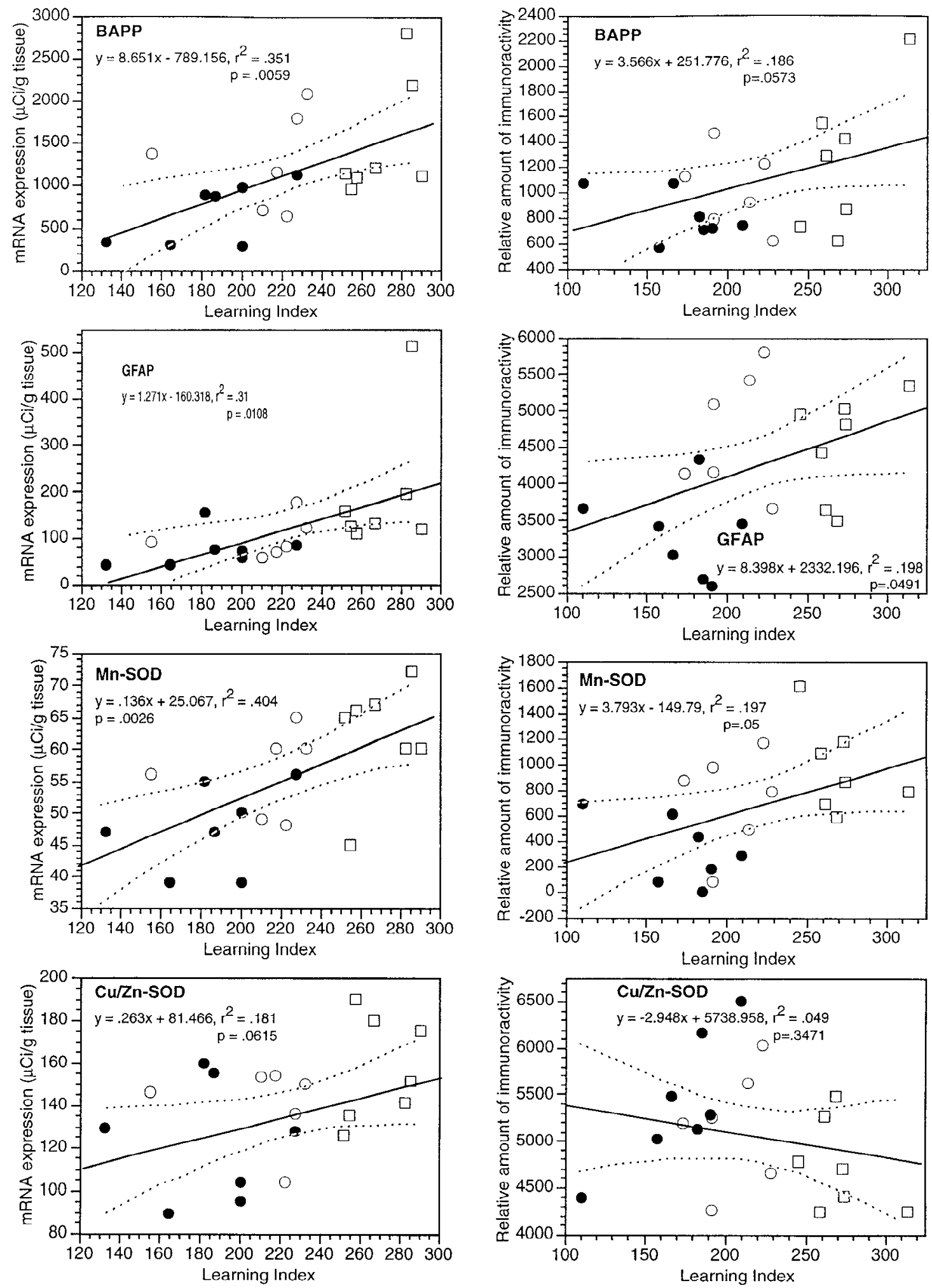

Figure 5. Levels of mRNA (left column) and corresponding proteins (right column) in the dorsal striatum of young and aged Long-Evans rats, plotted versus the learning index. Twenty rats were used in the ISHH experiments ( 7 young and 13 aged), and another 20 rats were used for protein analyses. The data for young rats are plotted as filled symbols, and the aged rats are shown as open symbols. The aged subjects are further delineated as "aged-unimpaired" (open circles), or "aged-impaired" (open squares), according to whether their learning index was within the range of the young rats. The mRNA data were sampled using National Institutes of Health Image from scanned film autoradiographs, and each point is the average of levels in the striatum for several samples of each subject. The mRNA levels are calibrated according to the tissue equivalents determined from $\left[{ }^{14} \mathrm{C}\right]$ standards exposed on the films and corrected for film background. The levels of proteins were determined in striatal extracts by slot blotting; the levels shown are relative optical densities taken from scanned blots using the program National Institutes of Health Image. The $x$-axis is the scale of the learning indices, with better performance in the spatial task at the left end and poorer performance at the right end. 


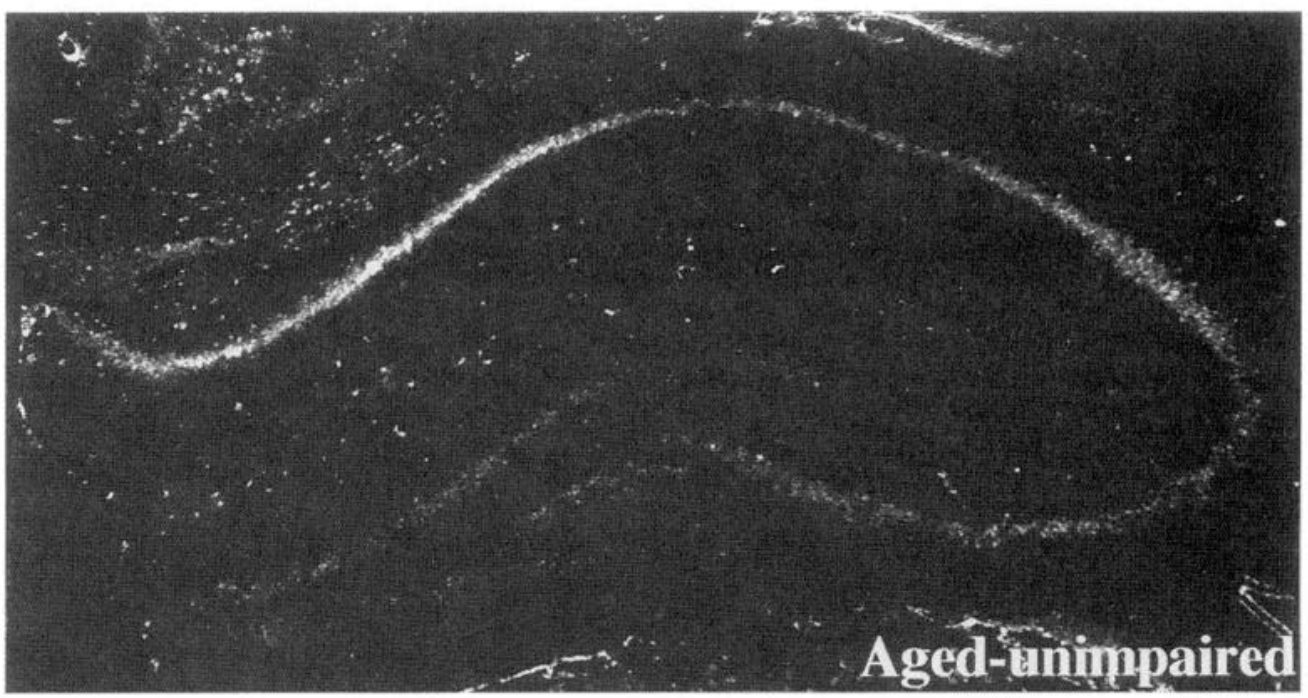

Figure 6. ISHH experiments localizing $\beta A P P$ mRNA in the hippocampal formation of two aged Long-Evans rats. These are digitized montages of dark-field views of emulsion-coated sections taken at low power $(25 \times)$ in the microscope. The top image is from an agedunimpaired rat (learning index $=218$ ), and the bottom image is from an agedimpaired rat (learning index $=286$ ).

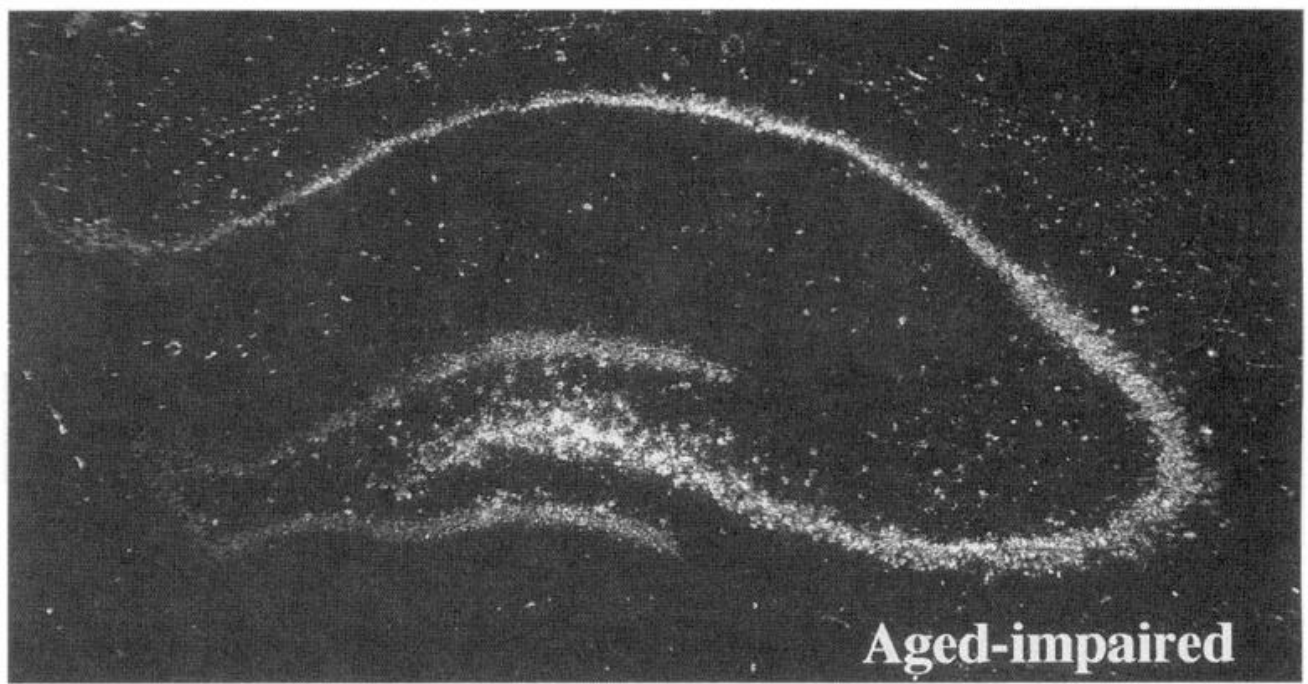

noticeably higher in the $\mathrm{CA}$ regions compared with the granule cells of the dentate gyrus. $\beta$ APP mRNA levels appear to increase throughout the hippocampal formation when the data for the aged rat are compared with data for the young rat. This experiment also suggests that the elevation of $\beta$ APP mRNA occurs mainly within pyramidal and granule neurons in the hippocampal formation. The astrocytes (GFAP-positive profiles) did not exhibit a significant $\beta$ APP expression with this time of exposure, indicating that the majority of $\beta A P P$ signal arises from other classes of cells. The fibers of these astrocytes appeared frequently to be in close proximity to presumptive neurons expressing high levels of $\beta A P P$ mRNA.

\section{Alterations of mRNAs in the dorsal striatum}

Four mRNAs were significantly correlated with the learning index in the hippocampus ( $\beta$ APP, b-NOS, GFAP, and Mn-SOD). It was of interest to survey other brain regions to determine the anatomical specificity of these alterations. Data for the striatum are presented here for comparison with results in the hippocampus. Figure 5 shows the data for mRNA levels, derived from film autoradiographs of the dorsal striatum; these data are plotted versus the individual learning index, whereas the top of Table 4 summarizes the statistical analyses of these mRNAs in the dorsal striatum using linear regression on data for all 20 subjects. The levels of the mRNAs for $\beta A P P, b-N O S$, GFAP, and Mn-SOD in the striatum were all positively correlated with impairment of performance in the spatial learning task. However, the level of $\mathrm{Cu} / \mathrm{Zn}$-SOD mRNA in the dorsal striatum was not altered significantly in the Long-Evans rats in any correlation with the learning index. These results suggest similarity between striatum and hippocampus of the effects of aging on the expression of candidate genes at the mRNA level. In contrast, our measurements of these mRNAs in brainstem revealed an effect only on GFAP $(r=0.83$; $p<0.05$; data not shown).

As shown in the bottom of Table 4, when striatal data from the aged subjects only $(n=13)$ were analyzed, none of the five markers in the striatum was significantly correlated with the learning index, which contrasts with findings in the hippocampus (Table 1). In the striatum of the aged cohort, the levels of b-NOS and $\beta A P P$ mRNAs were intercorrelated, and the level of GFAP mRNA was correlated with the levels of $\beta A P P$ and Mn-SOD mRNAs.

\section{Quantitation of proteins in the hippocampus and striatum using immunoblotting}

Initially, Western blotting was performed with antibodies to $\beta A P P, G F A P, M n-S O D$, and $\mathrm{Cu} / \mathrm{Zn}-\mathrm{SOD}$ to verify antibody specificity (examples are shown in Fig. 8). After conditions necessary for quantitation were established, slot blotting was used to obtain relative levels of these proteins in extracts of the whole 

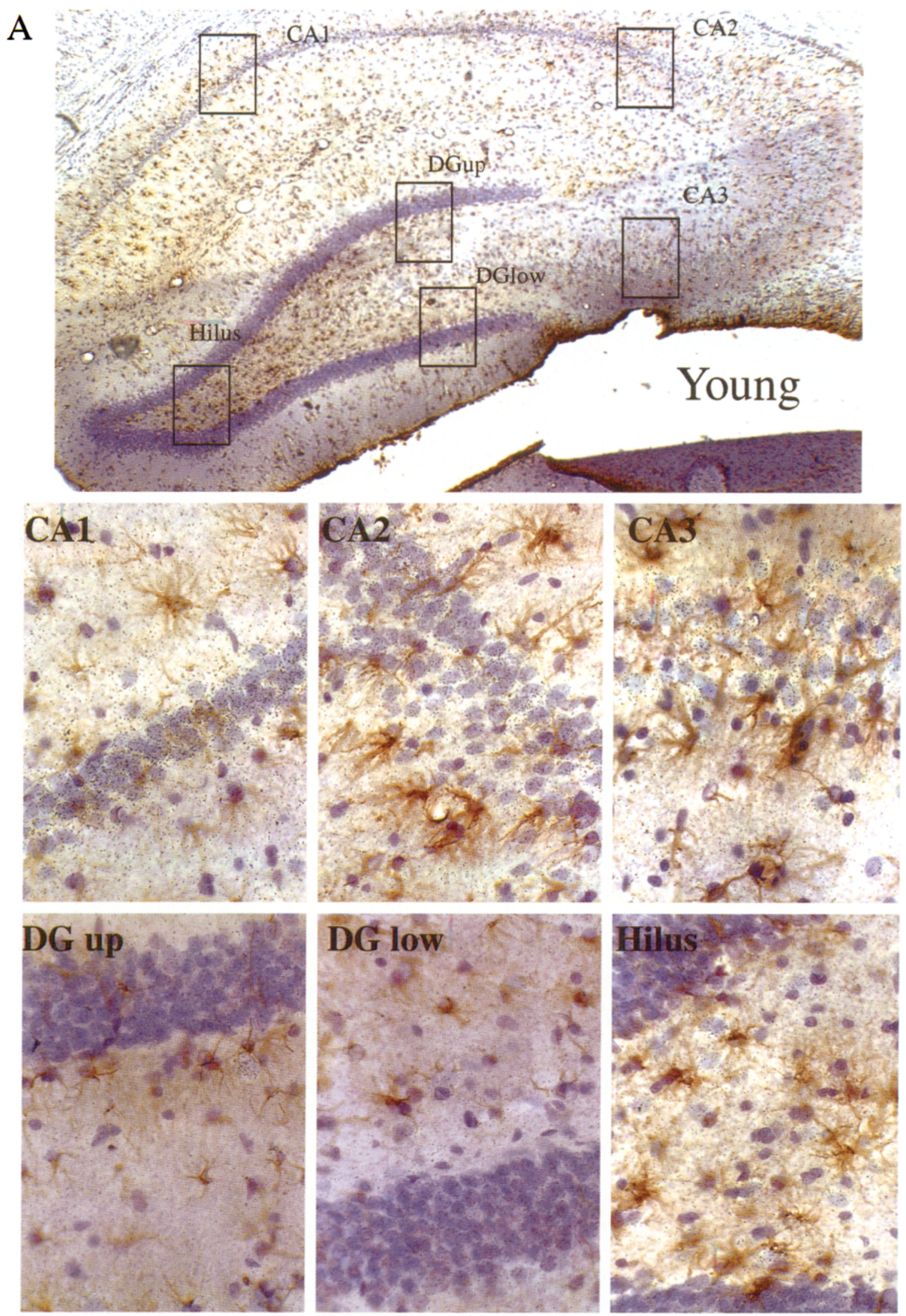

Figure 7. Immunohistochemistry for GFAP combined with ISHH for $\beta$ APP mRNA in the hippocampus of Long-Evans rats. Emulsion-coated sections, with cresyl violet counterstain. The brown deposits represent GFAP immunostaining, and the silver grains are localized within the emulsion coating the sections and over cells containing $\beta$ APP mRNA. There are two sets of images: one set for a young subject (learning index $=196)$ is shown in $A$, and one set for an aged-impaired subject (learning index $=269$ ) is shown in $B$. Each set contains a low-power $(25 \times)$ montage shown at the top, with boxes depicting 

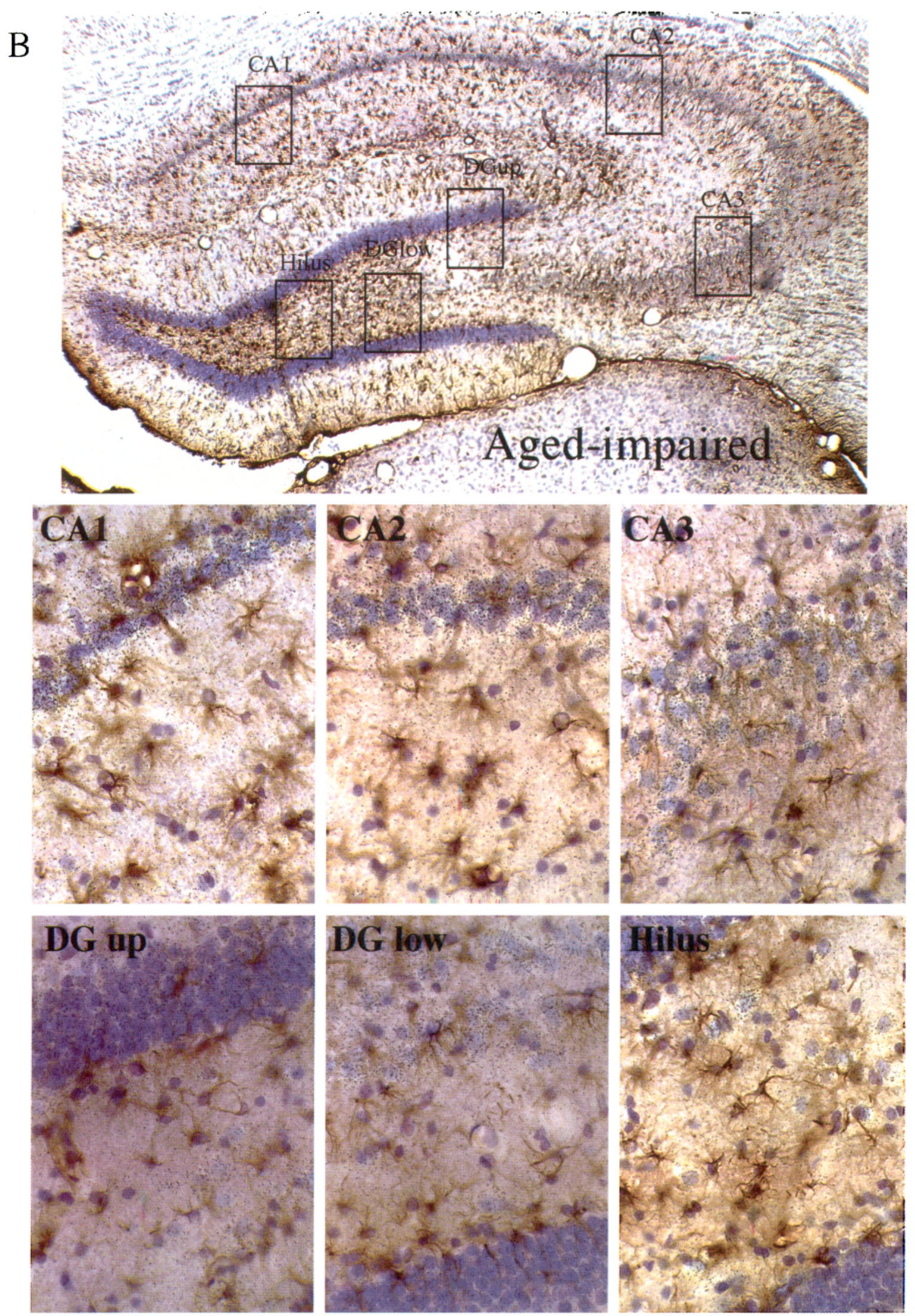

Figure 7 continued.

the areas enlarged in the six higher-power $(400 \times)$ views shown below the montage. The high-power views are of the CA1, CA2, CA3, hilus, upper blade of the dentate gyrus, and lower blade of the dentate gyrus. 
Table 4. Correlations between mRNAs, and between mRNA and the learning index, in the rostral dorsal striatum of young $(n=7)$ and aged $(n=13)$ Long-Evans rats combined (top), or for aged only (bottom)

\begin{tabular}{|c|c|c|c|c|c|}
\hline Marker & $\beta A P P$ & b-NOS & GFAP & Mn-SOD & $\mathrm{Cu} / \mathrm{Zn}-\mathrm{SOD}$ \\
\hline \multicolumn{6}{|c|}{ Analysis of data for all rats together (young $=7$; aged $=13$ ) } \\
\hline BAPP & & $0.84^{* * *}$ & $0.64 * *$ & $0.70^{* * *}$ & 0.36 \\
\hline b-NOS & & & $0.60^{* *}$ & $0.79 * * *$ & $0.57^{* *}$ \\
\hline GFAP & & & & $0.64 * *$ & 0.25 \\
\hline $\mathrm{Mn}-\mathrm{SOD}$ & & & & & $0.66^{* *}$ \\
\hline \multicolumn{6}{|l|}{ Learning } \\
\hline index & $0.59^{* *}$ & $0.52^{*}$ & $0.56^{*}$ & $0.64^{* *}$ & 0.43 \\
\hline Markcr & $\beta$ APP & b-NOS & GFAP & $\mathrm{Mn}-\mathrm{SOD}$ & $\mathrm{Cu} / \mathrm{Zn}-\mathrm{SOD}$ \\
\hline \multicolumn{6}{|c|}{ Analysis of data for aged rats only $(n=13)$} \\
\hline$\beta A P P$ & & $0.84^{* *}$ & $0.58^{*}$ & 0.49 & 0 \\
\hline b-NOS & & & 0.51 & $0.65^{*}$ & 0.27 \\
\hline GFAP & & & & $0.59 *$ & 0 \\
\hline $\mathrm{Mn}-\mathrm{SOD}$ & & & & & 0.46 \\
\hline \multicolumn{6}{|l|}{ Learning } \\
\hline index & 0.32 & 0.31 & 0.5 & 0.42 & 0.3 \\
\hline
\end{tabular}

The film autoradiographs used in Tables 1, 2, and 3 were sampled. For each subject and probc, the dorsal striatum between the rostral end of the globus pallidus and the genu of the corpus callosum was measured (typically $8-10$ samples for each subject). Linear regression was used to obtain the $r$ values for correlations between the averaged mRNA levels or between mRNA level and the learning index. Level of significance: ${ }^{*} p<0.05 ;{ }^{* *} p<0.01 ;{ }^{* * *} p<0.001$

hippocampus of a second set of 20 young and aged Long-Evans rats (plots of the data are presented in the right column of Fig. 4). For comparison, the levels of these proteins were also assessed in the striatum of these rats (these data are presented in the right column of Fig. 5). Tables 5 and 6 present protein marker intercorrelations in the hippocampus and striatum, respectively.

A commercial antibody that recognizes all the major members of the $\beta A P P / A P L P$ family revealed an array of proteins on the Western blot (Fig. 8); detailed studies with additional antibodies will be required to understand the effects of aging on individual $\beta A P P$ and/or APLP species. To gain insight into the effect of aging on this group of proteins as a whole, slot blotting of hippocampal and striatal extracts was performed. In contrast to the results we obtained with BAPP mRNA in the hippocampus, the aggregate level of $\beta$ APP-like protein was significantly reduced in hippocampal extracts from impaired rats, as shown in the composite plot of young and aged brain versus the learning index in the right column of Figure $4(r=-0.65 ; p<0.01$; also shown in the top of Table 5). This pattern of a decrease in BAPP-like protein was even more pronounced when only the aged rats $(n=$ 13) were analyzed $(r=-0.78 ; p<0.01$; see bottom of Table 5), indicating that the depression in level of this set of proteins is highly correlated with the degree of spatial learning dysfunction, and is not an "age effect." In the striatum, however, the level of $\beta A P P-l i k e$ protein was not depressed in subjects having higher learning indices; the right-hand plot for $\beta$ APP in Figure 5 shows that there was a trend for an increase in this marker in this brain region. The correlation coefficient $(r=0.43)$ bordered on statistical significance $(p=0.059$; see the top of Table 6$)$. The analysis of the aged cohort indicated a nonsignificant trend for an increase in BAPP level in the striatum (bottom of Table 6).

Western blots with an antibody for GFAP revealed a single band of $\sim 50 \mathrm{kDa}$ (Fig. 8). The levels of GFAP in hippocampus and striatal extracts of young and aged Long-Evans rats were assessed using a slot blot. The right columns of Figures 4 and 5 show plots of levels of GFAP in these two brain regions versus the individual learning indices. Measured as soluble protein, GFAP was not increased significantly in the hippocampus in relation to the learning index (Table 5), but in the striatum, there was an increase in GFAP that was correlated with the degree of behavioral dysfunction (Table 6). In the aged cohort, GFAP was not significantly correlated with the learning index in either hippocampus (bottom of Table 5) or striatum (bottom of Table 6).

Other immunoblotting cxperiments assessed the two SODs in the hippocampus and striatum of these 20 brains from young and aged rats. A single band for $\mathrm{Cu} / \mathrm{Zn}$-SOD protein was revealed with striatal extracts, whereas two bands for Mn-SOD protein were observed in Western blots (Fig. 8), which is consistent with previous reports (Kato et al., 1995). A slot blot analysis of $\mathrm{Cu}$ / $\mathrm{Zn}$-SOD in both striatum and hippocampus of the 20 young and aged subjects indicated that the levels of this protein were not altered significantly in relation to the learning index, in either the full data set or with the aged cohort only (see Tables 5 and 6). $\mathrm{Cu} / \mathrm{Zn}-\mathrm{SOD}$ protein levels in the striatum did exhibit significant negative correlations with $\beta A P P$ and Mn-SOD in the full data set (Table 6); these intercorrelationships did not occur in the hippocampus (Table 5). The level of Mn-SOD for young and aged subjects combined was negatively correlated with the learning index in the hippocampus (Fig. 4, Table 5), but positively correlated with the learning index in the striatum (Fig. 5, Table 6). When the data with the aged subjects were analyzed separately, there was a nonsignificant but positive correlation of Mn-SOD protein with the learning index in both brain regions (see the bottom of Tables 5 and 6). Thus, there was a pronounced decline of hippocampal Mn-SOD protein in aged-impaired rats, and this was essentially an age effect; in the striatum, there was an increase of this marker in more impaired subjects, and this is only partially an age effect.

\section{DISCUSSION}

In situ hybridization histochemistry was used to assess the levels of mRNA molecules for several candidate genes in the hippocampus and striatum in a rodent aging model in which the learning impairment was also assessed. The levels of proteins encoded by several of these mRNA molecules were measured in extracts of the hippocampus and striatum using immunoblotting methods. The steady-state levels of mRNAs for $\beta A P P$, GFAP, Mn-SOD, and b-NOS were increased in positive correlations with the learning index in both striatum and hippocampus. In analyses of the aged cohort only, the increases of these mRNAs in the striatum lost their significance, but hippocampal GFAP mRNA and MnSOD mRNA remained positively correlated with the learning impairment. $\beta \Lambda P P$ and Mn-SOD protein levels were markedly depressed in the hippocampus, but not in the striatum, of aged rats. The level of hippocampal $\beta$ APP-like immunoreactivity in the aged cohort retained its negative correlation with the learning index when data from the young group was removed. Immunoblotting studies further indicated that the astrocyte marker GFAP (protein) was considerably less affected than GFAP mRNA in the aged hippocampus.

Prcvious studies have reported increased GFAP mRNA in aged rodent hippocampus (O'Callaghan et al., 1991; Nichols et al., 1993; Kohama et al., 1995). Astrocyte hypertrophy in the hippocampus of aged rats has also been commonly observed and 

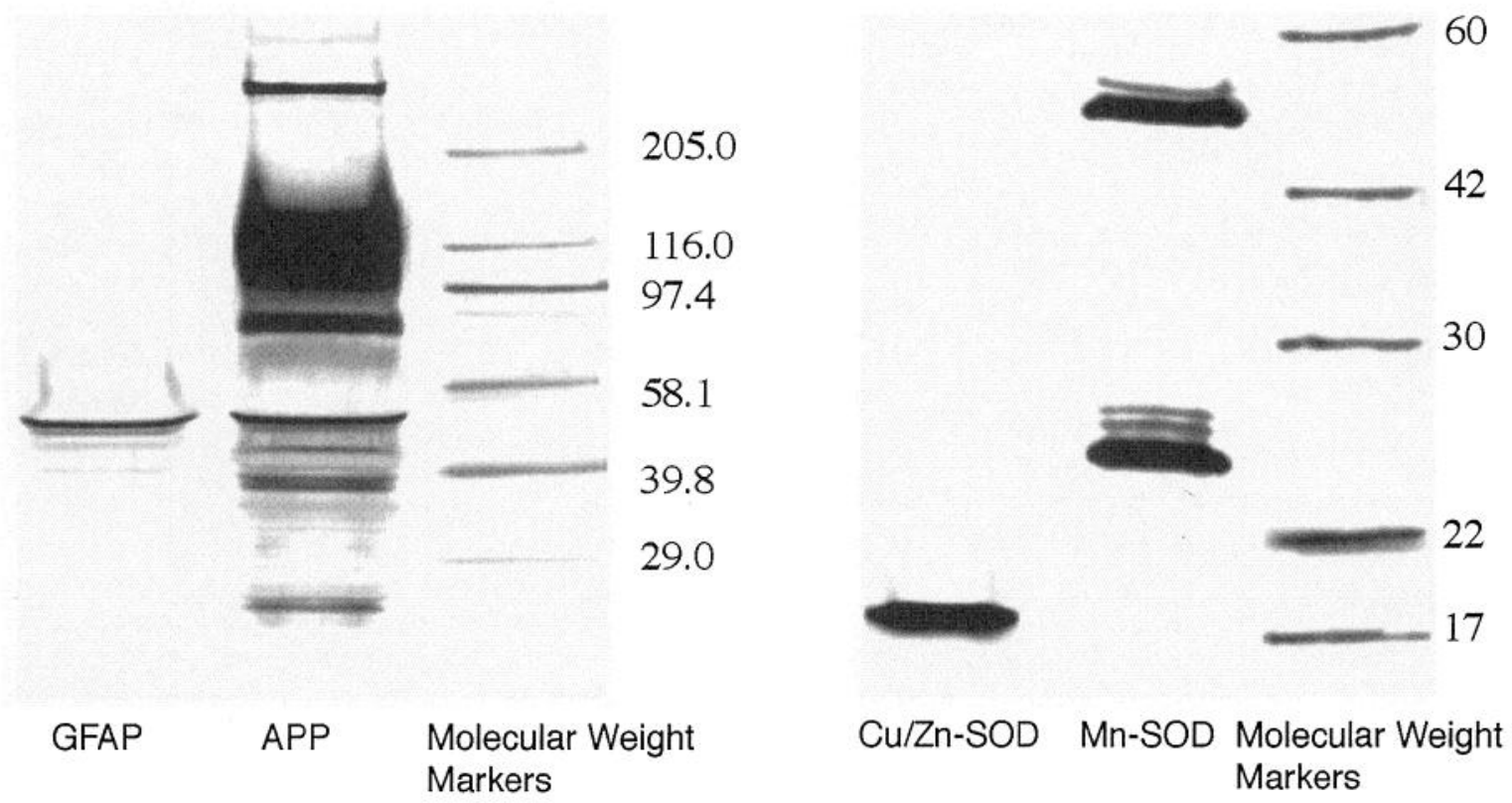

Figure 8. Western blots of proteins studied in the brains of young and aged Long-Evans rats. Electrophoresis was conducted with striatal protein extracts on polyacrylamide gels; after transfer, the blots were processed with antibodies specific for $\beta$ APP/APLP, GFAP, Mn-SOD, and Cu/Zn-SOD. These are digitized images of scanned blots from separate experiments.

viewed as a reaction to neurodegeneration; certain treatments that prevented age-related decline in hippocampal neuron density were reported to concurrently prevent hypertrophy of astrocytes (Landfield et al., 1978). It should be noted, however, that recent examination of the study population of aged Long-Evans rats used for the current research revealed no loss of granule or pyramidal neurons in the hippocampal formation assessed by optical fractionator techniques (P. Rapp, personal communication). However, apart from frank neurodegeneration, astrocyte reactivity in the aged hippocampus could occur secondary to age-related loss of synapses and/or dendritic atrophy. Our findings extend previous studies in demonstrating that an age-related

Table 5. Correlations between hippocampal protein levels and the learning index

\begin{tabular}{|c|c|c|c|c|}
\hline Marker & $\beta$ APP & GFAP & Mn-SOD & $\mathrm{Cu} / \mathrm{Zn}-\mathrm{SOD}$ \\
\hline \multicolumn{5}{|c|}{ Analysis of data for all rats together $($ young $=7$; aged $=13$ ) } \\
\hline$\beta A P P$ & & -0.08 & 0.12 & -0.13 \\
\hline GFAP & & & 0.04 & -0.26 \\
\hline Mn-SOD & & & & -0.15 \\
\hline Learning index & $-0.65^{* *}$ & 0.12 & $-0.59^{* *}$ & 0.31 \\
\hline Marker & $\beta A P P$ & GFAP & $\mathrm{Mn}-\mathrm{SOD}$ & $\mathrm{Cu} / \mathrm{Zn}-\mathrm{SOD}$ \\
\hline
\end{tabular}

Analysis of data for aged rats only $(n=13)$

\begin{tabular}{|c|c|c|c|c|}
\hline$\beta A P P$ & & -0.14 & -0.21 & -0.46 \\
\hline GFAP & & & 0.0 & -0.06 \\
\hline Mn-SOD & & & & 0.46 \\
\hline Learning index & $-0.78^{\text {** }}$ & 0.35 & 0.32 & 0.36 \\
\hline
\end{tabular}

Extracts of the hippocampus from 7 young and 13 aged Long-Evans rats were immunoblotted and screened for reactivity with antibodies to the indicated proteins. Linear regression was used to obtain the $r$ values for correlations between protein levels and between protein levels and the learning index. The top of the table contains analyses with all 20 subjects; the bottom of the table contains analyses of the aged cohort only $(n=13)$. Level of significance: ${ }^{*} p<0.05 ;{ }^{* *} p<0.01 ;{ }^{* *} p<0.001$. increase in GFAP mRNA in hippocampus is strongly correlated with severity of spatial learning impairment.

The level of $\beta$ APP mRNA in hippocampus, although exhibiting more variance than mRNA for GFAP, was also correlated with spatial learning performance. These results using ISHH are in agreement with our previous study using RT/PCR, which showed a similar elevation for the 695 form of $\beta$ APP mRNA, but not for the $\beta$ APP-751 or $\beta$ APP-770 forms, in aged learning-impaired rats (Greene et al., 1992). These results contrast with a report that BAPP mRNA, which contain an inserted Kunitz-type serine protease inhibitor motif ( $\beta$ APP-751, $\beta A P P-770$, and $\beta$ APP-related 563 ), are increased relative to the noninserted form ( $\beta$ APP-695)

Table 6. Correlations between striatal protein levels and the learning index

\begin{tabular}{|c|c|c|c|c|}
\hline Marker & $\beta A P P$ & GFAP & Mn-SOD & $\mathrm{Cu} / \mathrm{Zn}-\mathrm{SOD}$ \\
\hline \multicolumn{5}{|c|}{ Analysis of data for all rats together (young $=7 ;$ aged $=13$ ) } \\
\hline$\beta A P P$ & & 0.44 & 0.44 & $-0.46^{*}$ \\
\hline GFAP & & & $0.54 *$ & -0.25 \\
\hline Mn-SOD & & & & $-0.47^{*}$ \\
\hline Learning index & 0.43 & $0.45^{*}$ & $0.44^{*}$ & -0.22 \\
\hline Marker & $\beta$ APP & GFAP & Mn-SOD & $\mathrm{Cu} / \mathrm{Z}$ \\
\hline
\end{tabular}

Analysis of data for aged rats only $(n=13)$

$\begin{array}{llllr}\beta \text { APP } & & 0.28 & 0.18 & -0.43 \\ \text { GFAP } & & & 0.14 & 0.17 \\ \text { Mn-SOD } & & & & -0.28 \\ \text { Learning index } & 0.38 & 0.06 & 0.21 & -0.35\end{array}$

Extracts of striatal tissue from 7 young and 13 aged Long-Evans rats were immunoblotted and screened for reactivity with antibodies to the indicated proteins. Linear regression was used to obtain the $r$ values for correlations between protein levels and between protein levels and the learning index. The top of the table contains analyses with all 20 subjects; the bottom of the table contains analyses of the aged cohort only $(n=13)$. Level of significance: ${ }^{*} p<0.05 ;{ }^{* *} p<0.01 ;{ }^{* * *} p<0.001$. 
of BAPP mRNA in the basal forebrain of aged rats (Higgins et al., 1990). Specific age- and behavior-related changes in cortical $\beta$ APP immunoreactivity has also been reported (Beeson et al., 1994b). The current study further revealed increases in the levels of b-NOS and Mn-SOD mRNAs; in the case of the latter, a significant relationship was evident with the severity of spatial learning impairment in the aged rats. In contrast, no reliable change in the mRNA for $\mathrm{Cu} / \mathrm{Zn}$-SOD was found in any brain region, indicating that the effects of aging are limited to certain target genes.

Several features of the results indicate regional specificity in the effects of aging on the mRNAs that were examined. In the regional analysis of the hippocampal formation, a preponderance of alterations occurred in the dentate gyrus, particularly in the granule cell layer of the inferior blade of the dentate gyrus, where correlations with behavior and correlations among the mRNAs were the most numerous. In addition to these many effects in the dentate gyrus, a strong correlation between Mn-SOD mRNA and age-related behavioral impairment was evident in the CA2/CA3 region. The findings for hippocampus as a whole also stand in contrast to the striatum, where all correlations of mRNAs with learning index in the aged rats were not statistically significant.

Further regionally distinct features of our data emerged when protein levels were examined in hippocampus and striatum. In contrast to the patterns of alterations in the steady-state levels of certain mRNAs, which changed in parallel in the two structures, the levels of proteins were differently affected in hippocampus and striatum. In hippocampus, there were marked decreases in $\beta A P P$ and $\mathrm{Mn}-\mathrm{SOD}$ protein and no discernible increase in GFAP protein, despite considerable increases in the mRNAs for these proteins. These disparities between protein and mRNA in hippocampus were striking and differed from the increases in proteins observed in the striatum. These anatomically distinct differential patterns of marker alterations, which relate to age and behavioral status, suggest that clues regarding mechanisms underlying alterations in cognitive function might be found by further biochemical analysis of the $\beta$ APP, Mn-SOD, and GFAP systems.

There are several caveats to bear in mind with regard to the interpretation of the relevance of $\mathrm{mRNA}$ and protein alterations in our aging data. Because immunocytochemical signals are difficult to reliably quantitate in situ, relative levels of proteins encoded by candidate genes were assessed with immunoblotting techniques and protein extracts from whole hippocampus and striatum. Consequently, the specific cell populations in which proteins are altered in level were not identified or localized to the same degree as the mRNA markers were (although mRNA levels in Figs. 3 and 4 were from "whole" hippocampus, and thus are more or less equivalent to the level of analyses of protein). Similarly, because most of the mRNA quantitations involved film autoradiographs, as opposed to grain counting in emulsion-coated sections, the cellular sources of some of the mRNA alterations were not revealed (with the exception of $\beta A P P$ and GFAP mRNAs). The measures of protein and mRNA were made in different, albeit behaviorally similar, sets of Long-Evans rats; in the ideal experiment, all measures would have been made on the same subjects. Finally, the specific causes of the changes in immunoreactivity observed in the slot blot analyses need to be examined further with other biochemical approaches.

Despite these limitations, several points can be made regarding the probable cellular locations of the various marker alterations we observed. GFAP is generally viewed as a specific marker for astrocytes. b-NOS is thought to be essentially specific for neurons in the brain (Moncada et al., 1991). The major mRNA in brain for $\beta A P P$ codes for the 695 amino acid form, and this is thought to be expressed primarily in neurons. The other biochemical systems exist in both glia and neurons, although in our experiments the stronger Mn-SOD signals arise mainly from neurons (our unpublished data). In the present study, GFAP immunostaining combined with ISHH for $\beta$ APP mRNA did demonstrate that in the hippocampus of the aged-impaired Long-Evans rat, the astrocytes per se are not the major source of the increased expression of $\beta A P P$ mRNA. This contrasts with $\beta A P P$ responses in glial cells in ischemia (Siman et al., 1989). In the cognitively impaired aged brain, we observed $\beta A P P$ mRNA increases predominantly in presumptive pyramidal and granule cells of the hippocampal formation.

The increases in GFAP mRNA and Mn-SOD mRNA in the hippocampus, which correlated with the learning index, retained their significance when the young rat data were removed. Elevated GFAP mRNA and Mn-SOD mRNA in the aged hippocampus are thus directly and positively correlated with the extent of behavioral dysfunction. On the other hand, the significant correlation of hippocampal $\beta$ APP mRNA levels and the learning index, found in the combined group of young and aged rats, disappeared when only the aged subjects were analyzed. Although this seems to indicate that GFAP and Mn-SOD changes are more behaviorally relevant than $\beta A P P$, a different conclusion is reached when the protein data are examined. There was a substantial decrease in hippocampal Mn-SOD protein in relation to the learning index that was largely an effect of chronological age. Indeed, Mn-SOD protein exhibited a trend to increase in relation to learning impairment in the cohort of aged rats. Hippocampal GFAP protein was relatively unchanged in relation to either age or behavioral status. In contrast, the negative relationship between the learning index and the level of $\beta$ APP-like immunoreactivity in hippocampal protein extracts was actually strengthened when only aged subjects were considered. When these findings with protein are taken together with the data for $\beta A P P$ mRNA, it is apparent that behavioral impairment in aged rats is associated with a disparity between steady-state mRNA and protein; the more impairment in the spatial learning task, the greater the disparity between mRNA and $\beta A P P-l i k e$ protein in the aged hippocampus. This was not the case for either GFAP or Mn-SOD.

Possible functional relationships between hippocampal $\beta A P P$ and $\mathrm{Mn}-\mathrm{SOD}$, however, are suggested by the results. The levels of $\beta A P P$ and Mn-SOD mRNAs were strongly correlated both in the combined group of young and aged animals, and in the aged rats alone. In contrast to the increases in mRNA levels, the blotting experiments indicated reduced immunoreactivity of both $\beta A P P$ and $\mathrm{Mn}-\mathrm{SOD}$ in aged hippocampus. If this indicates a reduction in the level of expression of these proteins, it is unlikely to reflect a general deficiency in protein-synthetic capacity, given data in the current study and evidence reported elsewhere that other proteins in hippocampus are not reduced in learning-impaired aged LongEvans rats (Chouinard et al., 1995).

Alterations in $\beta$ APP expression and/or metabolism are commonly found in a number of neuropathological conditions, including AD (Cohen et al., 1988; Neve et al., 1990), and in the sequelae to ischemia (Kalaria et al., 1993; Sola et al., 1993) and other forms of brain injury (Anezaki et al., 1992; Iverfeldt et al., 1993; Wallace et al., 1993; Bceson ct al., 1994b). As in the case of normal aging, oxidative stress, free radical damage, and altered expression of SOD also occur in these conditions. Mn-SOD expression is typically increased in cells or tissues under oxidative stress and is 
generally observed to be more responsive than $\mathrm{Cu} / \mathrm{Zn}-\mathrm{SOD}$. I Thus, the correlated alterations in $\beta$ APP and Mn-SOD in the aged brain could reflect conditions of oxidative stress and this suggests that assessment of lipid, protein, or DNA peroxidative damage in the aged Long-Evans rat brain will also reveal correlations with behavioral impairment. The parallel alterations in $\beta$ APP and Mn-SOD also suggest that the perturbations of these systems may be occurring within the same cell populations in the hippocampus. Finally, the proximity of astrocytes (possibly "activated") to hippocampal cells in which $\beta$ APP mRNA elevation occurs suggests that studies of the relationships between gliosis and neuronal function in the aging brain would yield further insight into mechanisms underlying age-related cognitive dysfunction.

\section{REFERENCES}

Adams I, Jones DG (1982) Synaptic remodeling and astrocytic hypertrophy in rat cerebral cortex from early to late adulthood. Neurobiol Aging 3:179-186.

Adams Jr JD, Klaidman LK, Odunze IN, Shen HC, Miller CA (1991) Alzheimer's and Parkinson's disease. Brain levels of glutathione, glutathione disulfide, and vitamin E. Mol Chem Neuropathol 14:213-226.

Anezaki T, Yanagisawa K, Takahashi H, Nakajima T, Miyashita K, Ishikawa A, Ikuta F, Miyatake T (1992) Remote astrocytic response of prefrontal cortex is caused by the lesions in the nucleus basalis of Meynert, but not in the ventral tegmental area. Brain Res 574:63-69.

Baglioni C (1992) Mechanisms of cytotoxicity, cytolysis, and growth stimulation by TNF. In: Tumor necrosis factors: the molecules and their emerging role in medicine. (Beutler B, ed), pp 425-435. New York: Raven.

Beal MF (1992) Does impairment of energy metabolism result in excitotoxic neuronal death in neurodegenerative illnesses? Ann Neurol 31:119-130.

Beeson JG, Shelton ER, Chan HW, Gage FH (1994a) Differential distribution of amyloid protein precursor immunoreactivity in the rat brain studied by using five different antibodies. J Comp Neurol 342:78-96.

Beeson JG, Shelton ER, Chan HW, Gage FH (1994b) Age and damage induced changes in amyloid protein precursor immunohistochemistry in the rat brain. J Comp Neurol 342:69-77.

Behl C, Davis JB, Lesley R, Schubert D (1994) Hydrogen peroxide mediates amyloid beta protein toxicity. Cell 77:817-827.

Butterfield DA, Hensley K, Harris M, Mattson M, Carney J (1994) Beta-amyloid peptide free radical fragments initiate synaptosomal lipoperoxidation in a sequence-specific fashion: implications to Alzheimer's disease. Biochem Biophys Res Commun 200:710-715.

Chouinard M, Gallagher M, Yasuda RP, Wolfe BB, McKinney M (1995) Hippocampal muscarinic receptor function in spatial learning-impaired aged rats. Neurobiol Aging 6:955-963.

Cohen ML, Golde TE, Usiak MF, Younkin LH, Younkin SG (1988) In situ hybridization of nucleus basalis neurons shows increased betaamyloid mRNA in Alzheimer disease. Proc Natl Acad Sci USA 85:1227-1231.

Dawson DA (1994) Nitric oxide and focal cerebral ischemia: multiplicity of actions and diverse outcome. Cerebrovasc Brain Metab Rev 6:299-324.

Fahrig T (1994) Changes in the solubility of glial fibrillary acidic protein after ischemic brain damage in the mouse. J Neurochem 63:1796-1801.

Furuta A, Price DL, Pardo CA, Troncoso JC, Xu ZS, Taniguchi N, Martin LJ (1995) Localization of superoxide dismutases in Alzheimer's disease and Down's syndrome neocortex and hippocampus. Am J Pathol 146:357-367.

Gabuzda D, Busciglio J, Chen LB, Matsudaira P, Yankner BA (1994) Inhibition of energy metabolism alters the processing of amyloid precursor protein and induces a potentially amyloidogenic derivative. $J$ Biol Chem 269:13623-13628.

Gallagher M, Burwcll R, Burchinal M (1993) Severity of spatial learning impairment in aging: development of a learning index for performance in the Morris water maze. Behav Neurosci 107:618-626.

Geinisman YB, Bondareff W, Dodge JT (1978) Hypertrophy of astroglial processes in the dentate gyrus of the senescent rat. $\Lambda \mathrm{m} J \Lambda$ nat $153: 537-544$.
Giulian D, Li J, Li X, George J, Rutecki PA (1994) The impact of microglia-derived cytokines upon gliosis in the CNS. Dev Neurosci $16: 128-136$.

Goodman Y, Mattson MP (1994) Secreted forms of beta-amyloid precursor protein protective hippocampal neurons against amyloid betapeptide-induced oxidative injury. Exp Neurol 128:1-12.

Greene R, Robbins M, Gallagher M, McKinney M (1992) Measuring changes in transcript levels for various genes in the medial septum and hippocampus of rats due to age and memory impairment. Soc Neurosci Abstr 18:1481.

Halliwell B, Gutteridge JMC (1989) Free radicals in biology and medicine. Oxford: Claredon.

Harris ME, Hensley K, Butterfield DA, Leedle RA, Carney JM (1995) Direct evidence of oxidative injury produced by the Alzheimer's betaamyloid peptide $(1-40)$ in cultured hippocampal neurons. Exp Neurol 131:193-202.

Higgins GA, Oyler GA, Neve RL, Chen KS, Gage FH (1990) Altered levels of amyloid protein precursor transcripts in the basal forebrain of behaviorally impaired aged rats. Proc Natl Acad Sci USA 87:3032-3036.

Hilbich C, Monning U, Grund C, Masters CL, Beyreuther K (1993) Amyloid-like properties of peptides flanking the epitope of amyloid precursor protein-specific monoclonal antibody 22C11. J Biol Chem 268:26571-26577.

Hiraishi H, Terano A, Razandi M, Sugimoto T, Harada T, Ivey KJ (1992) Role of cellular superoxide dismutase against reactive oxygen metabolite injury in cultured bovine aortic endothelial cells. J Biol Chem 267:14812-14817.

Iverfeldt K, Walaas SI, Greengard P (1993) Altered processing of Alzheimer amyloid precursor protein in response to neuronal degeneration. Proc Natl Acad Sci USA 90:4146-4150.

Kalaria RNB, Bhatti SU, Palatinsky EA, Pennington DH, Shelton ER, Chan HW, Perry G, Lust WD (1993) Accumulation of the beta amyloid precursor protein at sites of ischemic injury in rat brain. NeuroReport 4:211-214.

Kato H, Kogure K, Araki 'T, Liu XH, Kato K, Itoyama Y (1995) Immunohistochemical localization of superoxide dismutase in the hippocampus following ischemia in a gerbil model of ischemic tolerance. J Cereb Blood Flow Metab 15:60-70.

Kinoshita A, Yamada K, Kohmura E, Hayakawa T (1991) Human recombinant superoxide dismutase protects primary cultured neurons against hypoxic injury. Pathobiology 59:340-344.

Kinouchi H, Epstein CJ, Mizui T, Carlson E, Chen SF, Chan PH (1991) Attenuation of focal cerebral ischemic injury in transgenic mice overexpressing $\mathrm{CuZn}$ superoxide dismutase. Proc Natl Acad Sci USA $88: 11158-11162$

Kohama SG, Goss JR, Finch CE, McNeill TH (1995) Increases of glial fibrillary acidic protein in the aging female mouse brain. Neurobiol Aging 16:59-67.

Kurobe N, Inagaki T, Kato K (1990a) Sensitive enzyme immunoassay for human Mn superoxide dismutase. Clin Chim Acta 192:171-179.

Kurobe N, Suzuki F, Okajima K, Kato K (1990b) Sensitive enzyme immunoassay for human $\mathrm{Cu} / \mathrm{Zn}$ superoxide dismutase. Clin Chim Acta 187:11-20.

Laemmli UK (1970) Cleavage of structural proteins during the assembly of the head of bacteriophage '14. Nature 227:680-685.

Lafon-Cazal M, Culcasi M, Gaven F, Pietri S, Bockaert J (1993) Nitric oxide, superoxide and peroxynitrite: putative mediators of NMDAinduced cell death in cerebellar granule cells. Neuropharmacology 32:1259-1266.

Landfield PW, Rose G, Sandles L, Wohlstadter TC, Lynch G (1977) Patterns of astroglial hypertrophy and neuronal degeneration in the hippocampus of aged, memory-deficient rats. J Gerontol 32:3-12.

Landfield PW, Waymire JC, Lynch G (1978) Hippocampal aging and adrenocorticoids: quantitative correlations. Science 202:1098-1102.

Lindsey JD, Landfield PW, Lynch G (1979) Early onset and topographical distribution of hypertrophied astrocytes in hippocampus of aging rats: a quantitative study. J Gerontol 34:661-671.

Marklund SL, Adolfsson R, Gottfries CG, Winblad B (1985) Superoxide dismutase isoenzymes in normal brains and in brains from patients with dementia of Alzheimer type. J Neurol Sci 67:319-325.

Martins RN, Harper CG, Stokes GB, Masters CL (1986) Increased cerebral glucose-6-phosphate dehydrogenase activity in Alzheimer's disease may reflect oxidative stress. J Neurochem 46:1042-1045. 
Masuda A, Longo DL, Kobayashi Y, Appella E, Oppenheim JJ, Matsushima K (1988) Induction of mitochondrial manganese superoxide dismutase by interleukin 1. FASEB J 2:3087-3091.

Mattson MP, Cheng B, Culwell AR, Esch FS, Lieberburg I, Rydel RE (1993) Evidence for excitoprotective and intraneuronal calciumregulating roles for secreted forms of the beta-amyloid precursor protein. Neuron 10:243-254.

Moncada S, Palmer RM, Higgs EA (1991) Nitric oxide: physiology, pathophysiology, and pharmacology. Pharmacol Rev 43:109-142.

Neve RL, Rogers J, Higgins GA (1990) The Alzheimer amyloid precursor-related transcript lacking the beta/A4 sequence is specifically increased in Alzheimer's disease brain. Neuron 5:329-338.

Nichols NR, Day JR, Laping NJ, Johnson SA, Finch CE (1993) GFAP mRNA increases with age in rat and human brain. Neurobiol Aging $14: 421-429$

O'Callaghan JP, Miller DB (1991) The concentration of glial fibrillary acidic protein increases with age in the mouse and rat brain. Neurobiol Aging 12:171-174.

Pang XP, Ross NS, Park M, Juillard GJ, Stanley TM, Hershman JM (1992) Tumor necrosis factor-alpha activates nuclear factor kappa B and induces manganous superoxide dismutase and phosphodiesterase mRNA in human papillary thyroid carcinoma cells. J Biol Chem 267:12826-12830.

Pappolla MA, Omar RA, Kim KS, Robakis NK (1992) Immunohistochemical evidence of antioxidant stress in Alzheimer's disease. Am J Pathol 140:621-628.

Reiter RJ (1995) Oxidative processes and antioxidative defense mechanisms in the aging brain. FASEB J 9:526-533.

Selkoe DJ (1994) Cell biology of the amyloid beta-protein precursor and the mechanism of Alzheimer's disease. Annu Rev Cell Biol 10:373-403.

Siman R, Card JP, Nelson RB, Davis LG (1989) Expression of betaamyloid precursor protein in reactive astrocytes following neuronal damage. Neuron 3:275-285.
Slunt HH, Thinakaran G, Von Koch C, Lo ACY, Tanzi RE, Sisodia SS (1994) Expression of a ubiquitous, cross-reactive homologue of the mouse $\beta$-amyloid precursor protein (APP). J Biol Chem 269:2637-2644.

Smith-Swintosky VL, Pettigrew LC, Craddock SD, Culwell AR, Rydel RE, Mattson MP (1994) Secreted forms of beta-amyloid precursor protein protect against ischemic brain injury [published erratum appears in $\mathbf{J}$ Neurochem 63:1585]. J Neurochem 63:781-784

Sola C, Garcia-Ladona FJ, Mengod G, Probst A, Frey P, Palacios JM (1993) Increased levels of the Kunitz protease inhibitor-containing beta APP mRNAs in rat brain following neurotoxic damage. Brain Res Mol Brain Res 17:41-52.

Sugaya K, McKinney M (1994) Nitric oxide synthase gene expression in cholinergic neurons in the rat brain examined by combined immunocytochemistry and in situ hybridization histochemistry. Brain Res Mol Brain Res 23:111-125.

Sutherland G, Bose R, Louw D, Pinsky C (1991) Global elevation of brain superoxide dismutase activity following forebrain ischemia in rat. Neurosci Lett 128:169-172.

Towbin H, Staehelin T, Gordon J (1979) Electrophoretic transfer of proteins from polyacrylamide gels to nitrocellulose sheets: procedure and some applications. Proc Natl Acad Sci USA 76:4350-4354.

Wallace WA, Ahlers ST, Gotlib J, Bragin V, Sugar J, Gluck R, Shea PA, Davis KL, Haroutunian V (1993) Amyloid precursor protein in the cerebral cortex is rapidly and persistently induced by loss of subcortical innervation. Proc Natl Acad Sci USA 90:8712-8716.

Wong GH, Goeddel DV (1988) Induction of manganous superoxide dismutase by tumor necrosis factor: possible protective mechanism. Science 242:941-944.

Wong GH, Elwell JH, Oberley LW, Goeddel DV (1989) Manganous superoxide dismutase is essential for cellular resistance to cytotoxicity of tumor necrosis factor. Cell 58:923-931. 